Article

\title{
The 2001-2017 Façade Renovations of Jongno Roadside Commercial Buildings Built in the 1950s-60s: Sustainability of Ordinary Architecture within Regionality
}

\author{
Dai Whan An ${ }^{1, *(1)}$ and Jae-Young LEE ${ }^{2, *}$ \\ 1 Department of Architecture, Chungbuk National University, Cheongju 28644, Korea \\ 2 Institute of Engineering Research, Yonsei University, Seoul 03722, Korea \\ * Correspondence: an4229@cbnu.ac.kr (D.W.A.); muryumok@hotmail.com (J.-Y.L.); \\ Tel.: +82-4-3261-2434 (D.W.A.); +82-2-2123-8064 (J.-Y.L.)
}

Received: 27 July 2018; Accepted: 5 September 2018; Published: 12 September 2018

check for updates

\begin{abstract}
This paper examines 41 roadside commercial buildings of the Jongno region built in the 1950s-60s that received façade renovations between 2001 and 2017. The aim is to show the relations between the forms of renovation and the regionality of the commercial areas, which have been historically formed in the original city center of Seoul, as well as the relation of these connections to the sustainability of ordinary architecture. Because Jongno has been the city center for the 600 years following the Joseon dynasty, the region is still a center for politics, administration, economics, and culture. Specialized commercial areas exist in each region within Jongno, and each of these reflect their own regionality. Within such regionality, the roadside commercial buildings are adapting and changing to fit the times, and regionality is sustained through façade renovation of ordinary architecture. The façade renovations of roadside commercial buildings that reflect such regionality and sustainability do not involve redevelopment through overall demolition, which represents a loss of regionality and history and is conducted undemocratically; rather, the practice should be acknowledged for adding value as past heritage and the simultaneous incorporation of present and future values.
\end{abstract}

Keywords: façade renovation; roadside commercial buildings; ordinary architecture; Jongno; regionality; sustainability

\section{Introduction}

\subsection{Background and Purpose}

The Jongno region is the most representative city center of Seoul. Since the time of the Joseon dynasty, Jongno has served as the center of politics, economics, culture, and administration, and the most representative commercial area formed within it. This city center held the central commercial area even during the process of modernization in the 1960s. However, after the development of Gangnam (areas south of the Han river) in the 1970s, Jongno began to lose its commercial power, and has been in decline since the loss of its status as the main city center (Figure 1). Currently, the Jongno region, which spans from the Sejongno intersection to Dongdaemun, excluding a few areas of redevelopment, retains the typical form of the aging Korean city center. However, despite its aging process, it still symbolizes the city center of Seoul, and as the existing commercial areas of the city center are maintained, so too are the characteristics of each region, passed down over a long period (Figure 2). 


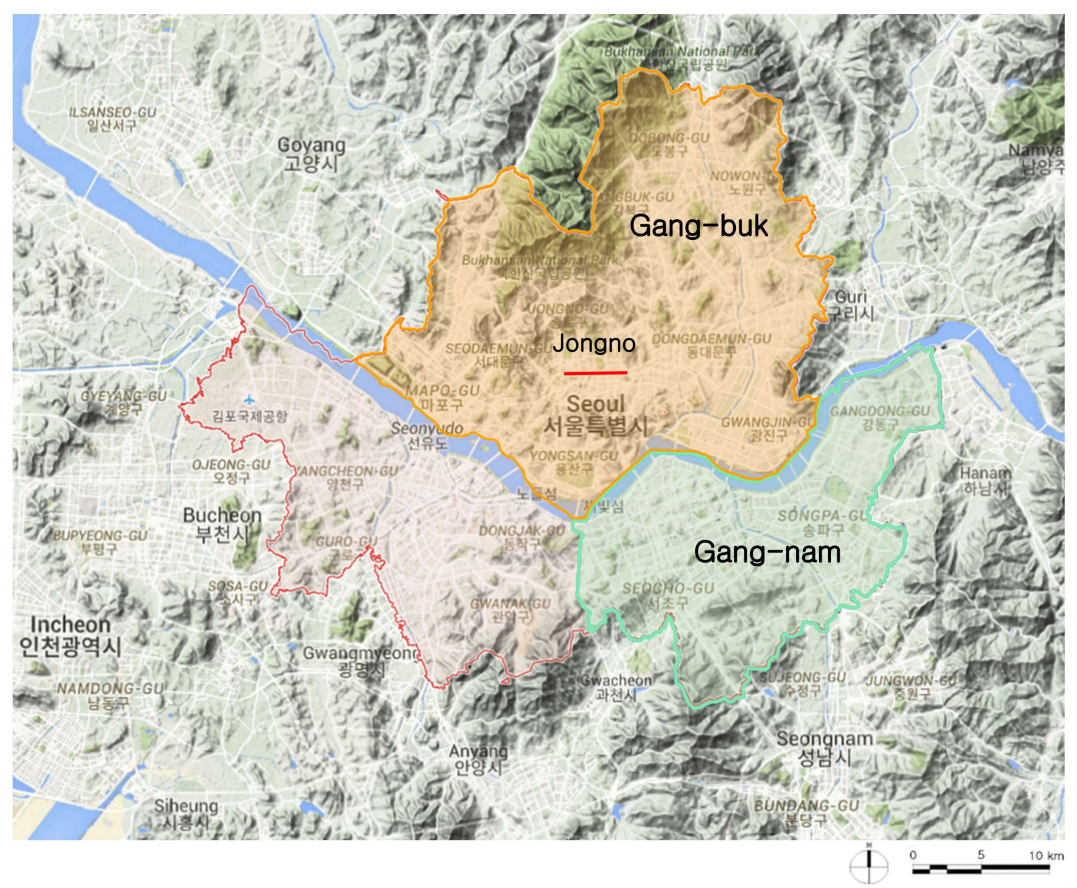

Figure 1. The map of Seoul.

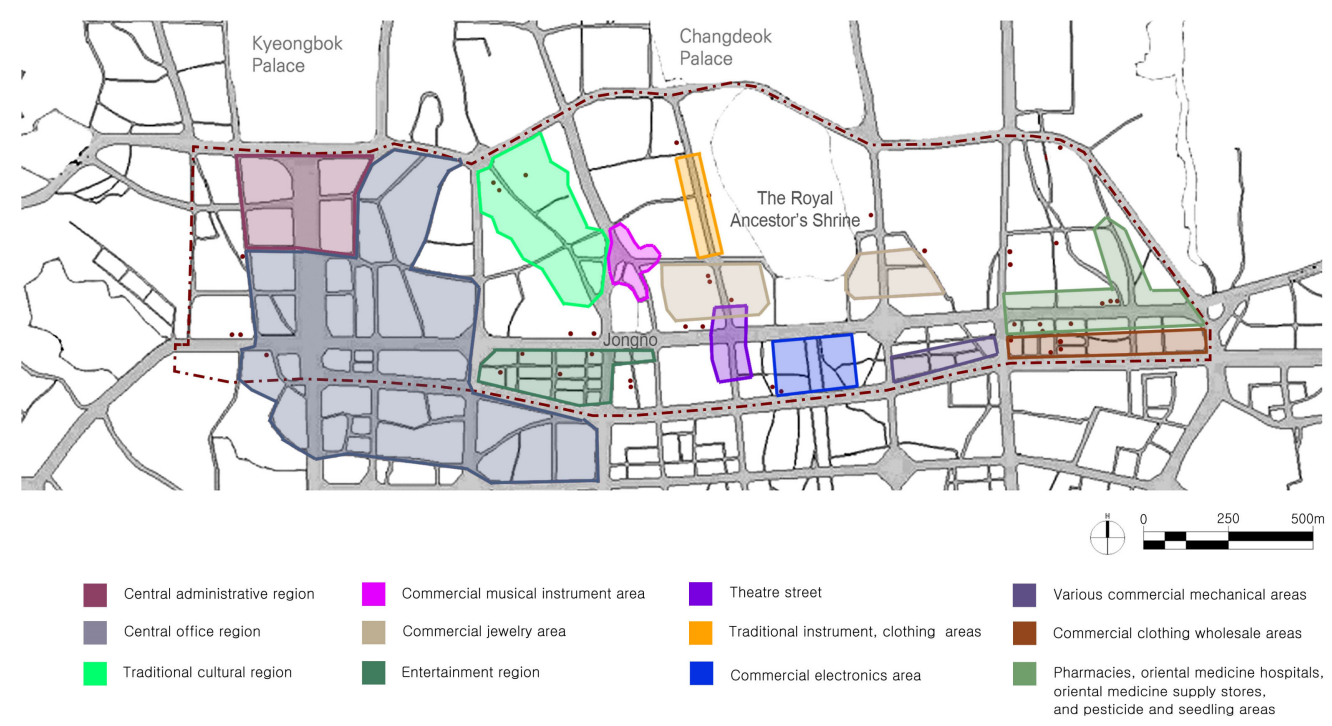

Figure 2. The specialized commercial areas in Jongno.

Within such regionality, aging commercial buildings that were newly built in the 1950s-60s as ordinary architecture have been improved in the 2000s and 2010s through renovation or major repairs, rather than being demolished and newly built. Because these are ordinary architecture, the aim is to increase profits by changing the condition of the buildings to fit current usages and trends with minimum investment; this is done through partial façade modification. Façade renovation is a passive architectural act that occurs following changes in period. It maintains the regionality and symbolism of Jongno, while at the same time incorporating the building materials and technologies, decoration trends, cultural background, and other modern factors of the 2000s and 2010s. In addition, façade renovation has an important role in maintaining the value of Jongno's heritage as the old city center.

There are many examples in practices and studies on the renewal of outdated buildings with historical value in the city center. It is a part of sustainable development, which overcomes problems with tabula rasa urban redevelopment, preserves cultural heritage value, and breathes vitality into 
the city. Renewal examples in various countries, however, have different contexts depending on the country, city, regional history, and type of building. As a similar example in East Asia, there is the adaptive reuse of traditional Chinese shophouses in an urban renewal project in Hong Kong. In the project, shophouses built from 1888 to 1940 in eight districts were renewed under the leadership of the government. In their study on this case, Esther H. K. Yung, Craig Langston, and Edwin H. W. Chan argue that each district's success in reuse and renewal belongs to a set of different circumstances, and it is necessary to consider a balance between future economic viability and cultural heritage value [1]. In addition, they reckon that it is only significant in terms of sustainability when the community's sustainability in social life and local identity are taken into account along with physical conditions. This case is about the renewal of commercial buildings in old districts, similarly to this paper.

As another example in Korea, there is a modern cultural heritage restoration project in Ganggyeong. Ganggyeong was a major commercial city during Japanese colonial rule in Korea (1910-1945), which connected inland and coastal areas through the river, but the city is now largely limited to the production and distribution of jeotgal (traditional Korean salted seafood). After its advantages as a transport hub vanished as other expressways were developed, the city declined, and modern buildings constructed during Japanese colonial rule were left abandoned. As the city restored them, it regained its vitality as a city of jeotgal festivals and heritage tourism. The restored buildings, however, have a limitation in that they are not used for contemporary commercial uses other than the jeotgal distribution industry and tourism industry [2].

Currently in Korea, city renewal projects are underway with national support. Notably, each city's declining original center was chosen as an urban renewal area. Projects in which Korea began to fully modernize itself by renewing outdated buildings established before present a challenge. The country is facing the challenge of creating new commercial uses, while preserving regionality such as the local community and buildings' cultural value.

Jongno is an example; its urban redevelopment, which demolished Gongpyeong-dong and Cheongin-dong and built new high-rise buildings in the 2000s, was a far cry from sustainable development in terms of historical value in the city center, regionality, and local residential gentrification. While recognizing such problems, the current Jongno Insa-dong redevelopment project is shifting toward a small-scale preservation development method. Against this backdrop, this study is significant for urban regeneration projects, as it reevaluates the renovation status of buildings built in the 1950s to 1960s in Jongno, considering regionality and sustainability.

In this research of façade renovation of Jongno roadside commercial buildings, 41 cases were analyzed to derive the elements of sustainability in urban structures related to the regionality of city structure that appears through such architectural actions.

As buildings in Jongno aged with the passage of time, some were maintained in their aged state, some were demolished and newly built, some were torn down as part of urban redevelopment, and 41 buildings underwent façade renovations or major repairs. These 41 buildings still have sufficient value as neighborhood living, commercial, and office facilities within their respective regions. Therefore, rather than being torn down and replaced by new structures, the buildings undergo façade renovation to erase some of the traces of the 1950s-60s, update them with modern designs, and increase their commercial value.

Unlike the façade designs of the 1950s-60s, which showed little variety due to the weak economic, cultural, and architectural circumstances of the time, modern façade designs are varied, and current façade renovations offer many options. These façade renovations sometimes demonstrate common and standard materials and designs, and sometimes poor-quality designs. However, this is characteristic of ordinary architecture, which is unlike high-end architecture. We aim to analyze the characteristics of façade renovation of roadside commercial buildings as ordinary architecture or urban architecture and to find their significance in relation to regionality and sustainability-how these façade renovations contain regionality and sustainability and how they change within the city structure-and consider the value of this heritage. 


\subsection{Research Target and Methodology}

Because the regional selection of Jongno as the target for investigation was based on material investigated in prior research by Jae-Young Lee [3], we followed the regional range of this precedent. The range of area for this study is confined to the area bordered by Cheonggye-ro in the south, Yulgok-ro fronting Changdeokgung palace in the north, Dongdaemun gate in the east, and Sinmun-ro in the west (Figure 2). This was selected as the range that could be affected by the central road of Jongno. In 2001, 161 buildings were visited and investigated using registered building data for Lee's study [3]. This paper refers to 41 of these 161 buildings, which underwent façade renovation between 2001 and 2017 (Figure 3). Through analysis of the 161 case studies in the Jongno region, the precedent study showed that the ordinary architecture newly built in the 1950s-60s exhibits the forms of modern architecture. This period, following liberation and the war, overcame weak economic circumstances and underdeveloped architectural planning and construction. The process of modernization and urbanization after the 1960s saw development from masonry structures to mixed masonry/reinforced concrete structures to reinforced concrete structures; as the latter gradually became common, modern architectural forms began to emerge and take root in popular architectural culture, such as horizontal windows, exposed concrete, rationalization of the core section, and so on. We confirmed the year in which façade renovation was conducted for 19 of the 41 buildings. (The year of renovation was confirmed through registered building data or yearly Internet street views using Daum (m.map.daum.net/actions.) However, we were not able to discover any meaningful change based on the temporal change between 2001-2017. Therefore, in this research, we did not consider year of renovation as a special factor for study.

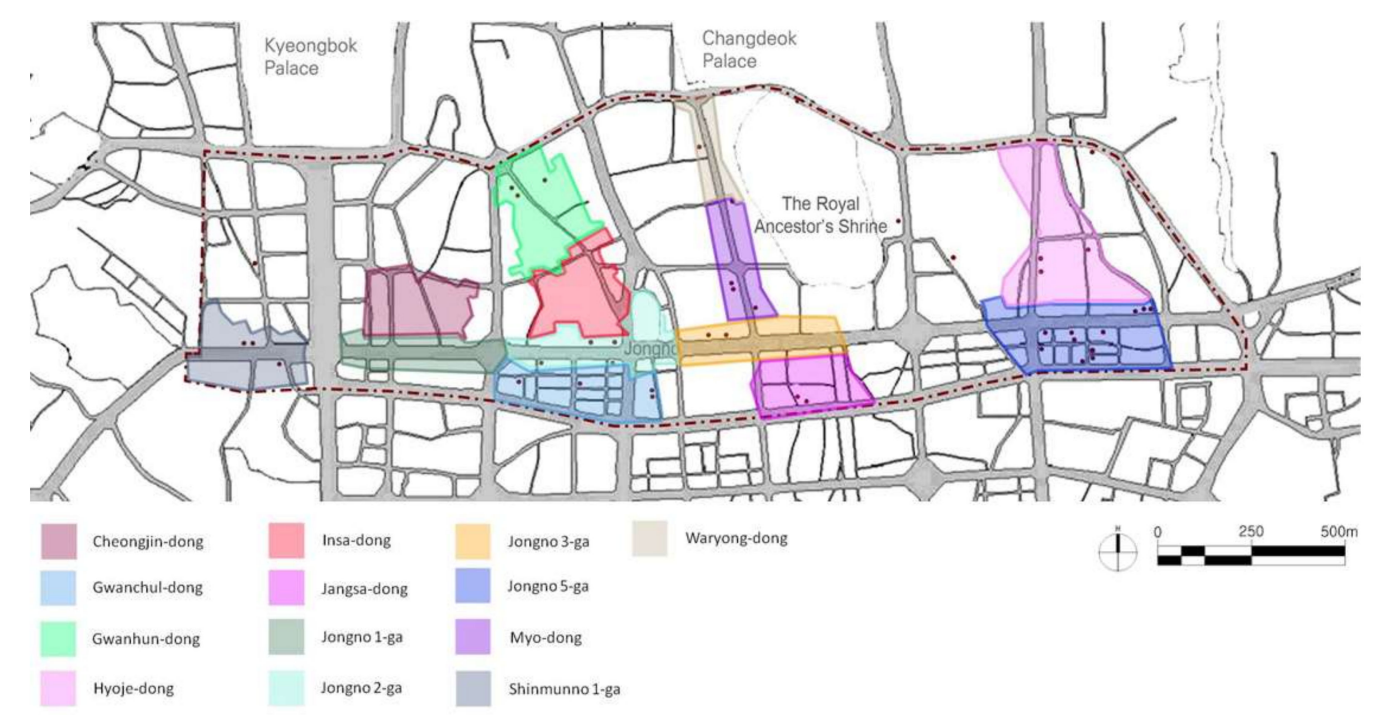

Figure 3. The range of area for this study and locational distribution of dongs and the example buildings.

The foremost concern of this research is the need to examine the concepts of regionality and sustainability. In addition, we summarize the meaning of ordinary architecture. We examine the meaning roadside commercial buildings as ordinary architecture have within their relationship with regionality and regional sustainability. Next, to identify the specific regionality and sustainability of the Jongno region, we investigate the history of Jongno, its function and symbolism as the city center, and its regional commercial areas. To analyze the investigated cases, we survey the locational distribution and the stores occupying the buildings. Furthermore, to analyze how the façades changed, we divide cases based on whether the façade renovation took a completely different direction from the building's structural system and previous façade, whether it was partially different, or whether it was similar. Based on this, we analyze the adaptation of façade renovation based on period changes and 
evaluate this adaptation in relation to urban structure sustainability as it relates to regional commercial areas. Finally, we aim to examine the heritage value of roadside commercial buildings in regionality and sustainability.

\section{Regionality, Sustainability, and Ordinary Architecture}

\subsection{Regionality and Sustainability}

Human worlds have boundaries and regional differences, fluid and multi-faceted though they might be. As Heidegger stated, humans are both "entities that are together with" (being-with) other beings, and entities that face outside themselves (being out for), and thus they create and live in innumerable worlds through their relationships with other entities. Humans create spaces, and those spaces become places. Thus, places are created out of the lives of humans. This is the basis for Heidegger's claim that "Dasein is special in a primordial sense [4]." Spaces that take on meaning from humans become places, regions, and areas. Therefore, "regionality" refers to specific characteristics, based on human interpretation, that differentiate a region occupying one locational position from other places [5]. That is, a region has a history created by humans through the passage of time, and through the process of being signified and re-signified, regionality is created and changed.

This paper asserts that the Jongno region has such characteristics, and aims to examine whether this influences the region's roadside commercial buildings. Jongno was the representative city center of Seoul during the 600-year history following the establishment of the Joseon dynasty. It is itself divided into many small and large areas. These internal regions have been preserved and have changed with the passage of time. Various areas formed from decades and centuries of political, administration, economic, and cultural activities, including the central administrative region, central office region, traditional cultural region, entertainment region, theatre street, commercial jewelry area, commercial musical instrument area, commercial electronics area, various commercial mechanical areas, commercial clothing wholesale areas, and so on. In addition, these areas have become significant as places and symbols to the Korean people.

This paper aims to seize the characteristics of façade renovation of roadside commercial buildings and evaluate their significance from the angle of sustainability, within the regionality of Jongno as a historical city center. Jongno is an amalgamation of activities accumulated through the passage of time and locations created through signification. Even as these factors change within the context of time and place, we can still discuss commercial activities, uses, and elevation forms of buildings, roads, and landscapes that are continuous. These elements can be interpreted as concepts of sustainability. Commercial activities in Jongno changed as recently as 20 to 30 years ago but certain activities remain the way they have been for a very long time, and the buildings and streets that include people's commercial activities create its local atmosphere. These areas in Jongno have specific meaning as places among the city's residents. Therefore, buildings and streets in various parts of Jongno serve as places of everyday activity and history, hold socio-cultural heritage value, and represent sustainability.

The combination of regionality and sustainability in such cultural heritage has been stated by many academics. It is because cultural heritage in a region is a combination of tangible and intangible things created by the surrounding environment and social relationships. Jukka Jokilehto suggests that there are authenticity and integrity in the heritage context. More importantly, he states the following about social-functional integrity:

The social-functional integrity of a place is referred to the identification of the functions and processes on which its development over time has been based, such as those associated with interaction in society, spiritual responses, utilization of natural resources, and movement of peoples [6].

Jokilehto holds that cultural heritage is not confined to tangible things, while regional characteristics are related to interaction between people and change over time. In addition, in this context of synthetic thinking, Elizabeth Auclair and Graham Fairclough posit that it is important 
for cultural heritage's socio-cultural sustainability that people use buildings, places, and landscapes every day:

Heritage, like cultural action, is rooted in space, as well as time, and is consequently, more often than not, place-based, site-specific, locality-sensitive, and community-contextualized. It is this everyday aspect and "use" that makes heritage—buildings, places, townscapes, landscapes—a key component of social and cultural sustainability [7].

People's activities, buildings, streets, and landscapes in Jongno have regionality that is distinctive from other regions. Notably, commercial activities in the original city center are rooted in the past and change and carry on even today; they will continue to do so in the future. Renovated roadside commercial buildings in Jongno's regionality are the products of the tangible and intangible from the past, present, and future. Hence, they are real and authentic. It is worth examining the meaning of roadside commercial buildings in Jongno from the perspective of regionality and sustainability, to accommodate the use for today's everyday life and prepare for a change in the future, while maintaining regionality created from the past.

\subsection{Regionality and Sustainability of Ordinary Architecture}

This study examines the regionality and sustainability of Jongno through its roadside commercial buildings. Roadside commercial buildings are neither monumental buildings within the city nor high-end architectural buildings, but rather buildings where day-to-day commercial activities occur, and where regionality and regional sustainability are reflected. These roadside commercial buildings are ordinary architecture, meaning general structures used for small- to medium-scale general purposes:

Ordinary works of architecture, not monumental ones-those of residential buildings, offices, small public infrastructures-are necessary to evidence the manner in which models, often from experts and avant-garde in style, are disseminated into the usual production and somehow make it into the public domain. Architecture by very sophisticated designers stands alongside less elaborate and anonymous works of a less complex flavor. Sometimes this second category is preexisting and enters the field of expert architecture when an architect takes hold of it [8].

In addition to the meaning of general and common, the term "ordinary" here also has a special meaning that differentiates these buildings from structures or works designed by famous architects. Ordinary structures are planned and constructed by small- and medium-size construction companies to meet the demands of the building owner. They do not involve the level of finishing or stylizing in terms of concept, technique, or esthetics that a work of architecture does. To obtain maximum spatial and decorative effect with limited funds, technical skill, and materials, cases sometimes demonstrate unbalanced plans and poor-quality imitations. This value of ordinary architecture is a reminder of the "learning from Las Vegas" of Robert Venturi, Denise Scott Brown, and Steven Izenour [9]. They accepted the ordinary landscape of roadside commercial buildings as a cultural environment related to multidimensional needs over the passage of time. Our view is that ever since they raised this question, ordinary architecture has borrowed from and given variation to high-end buildings; even though its quality level is somewhat lower, ordinary architecture uses language and symbols to be commercially convincing. Furthermore, although landscapes created by roadside commercial buildings are various, complex, and confusing, we believe they are the cultural landscapes that represent everyday life in the city center. Road networks in Jongno have been established and changed as far back as 600 years ago, or as recently as 60 years ago. In addition, roadside commercial buildings built from the 1950s to the 1980s, which underpin today's Jongno roadside landscape, are the products of that era in Korea. As the country underwent rapid modernization and urbanization, the International Style was popularized in a Korean way and the modern architectural style was applied belatedly to roadside commercial buildings. Also, today's façades renovated on top of Korea's borrowed modern architecture are the cultural landscapes in which architecture materials and techniques, façade design trends, and commercial language and symbols are applied in the context of Jongno, as well as Korea 
in the 21st century. Therefore, roadside commercial buildings, as ordinary architecture, are the best indicators of a region's political, economic, social, historical, cultural, and technical characteristics. They encompass the commonness of an era and the regionality of a place, and despite changing with the passage of time, still demonstrate sustainability related to regionality.

The heritage value of roadside commercial buildings with regionality and sustainability must be considered. This value can be viewed from various perspectives. For example, in Alois Riegl's book, Moderne Denkmalkultus: Sein Wesen und seine Entstehung (Modern Worship of Monuments: Its Origins and Characteristics), he divided it into three aspects: (1) historical value, (2) age value, and (3) intentional commemorative value. Historical value means that the higher the purity of the cultural heritage in maintaining its original form, the greater its value. Therefore, the aim is to prevent all weathering. Age value means that even those things that change with the passage of time are acknowledged for their value. Intentional commemorative value is manifest value tied necessarily to the original condition, and does not acknowledge changes that occurred after its creation [10]. This study focuses on age value, considering the value of moments that exist and remain in the present to be important. During the time between a monument's creation and the present, it changes, either naturally or artificially. Acknowledging age value implies that these changes do not lessen or destroy the monument's value, but instead sustain it. As stated by Marta de la Torre, heritage values are not intrinsic. They are multiple, mutable, incommensurable, often complicit [11]. The values created and sustained through the passage of time contribute a greater portion of the region's overall value than does the initial value that was present upon its creation. Age value also reveals historical regionality, defined as the process by which the characteristics of a region are determined and changed by the passage of time. That is, a region's age value is sustained by gaining meaning as historical culture. When the characteristics of an old region are maintained, conflicts between historical inertia and demands for modern change are unavoidable, and the changes that arise from such conflict, when viewed from the perspective of age value, allow for both maintenance of a region's cultural heritage value and development in a new direction. In Jongno, streets and buildings have been passed down from the past. They are the places that have memory and identity, and the cultural heritage of the present that includes everyday life needs and provides diversity in the city. Communities involved in commercial and other activities in Jongno lead their lives, and the city's residents take part and make meaning out of it; hence, it is the city center. Jongno is currently changing based on this foundation, and it is the cultural heritage that will continue to change in the future.

\section{The History of Jongno, Its Function and Symbolism as a City Center, and the Regional Economy}

\subsection{History of Jongno}

Jongno was historically the central road connecting the east to west axis of Hanyang, the capital of Seoul. It was the most representative commercial space in Joseon, so much so that it was called unjongga (雲從街, cloud gathering street). It was there that the gongrang (公廊), an old Korean type of store space lining the street) were constructed for merchants of the market, and to this day it remains the central commercial region of Seoul. The roadside gongrang in Jongno were occupied by stores; the merchants were also responsible for procurement activities targeting administration. Between the shijeonhaengnang (old Korean licensed stores) and the main road were temporary stores called gaga (假家), and Pimatgol, the back alley of Jongno, was a living space for merchants and a production and entertainment space including handicraft workshops, restaurants, brothels, bars, and so on [12] (Figure 4).

Although Jongno declined in importance during the period of Japanese occupation, it retained its position as the central commercial area for the Joseon people. During this time, newly constructed twoand three-story stores changed the landscape of the streets of Jongno streets. 


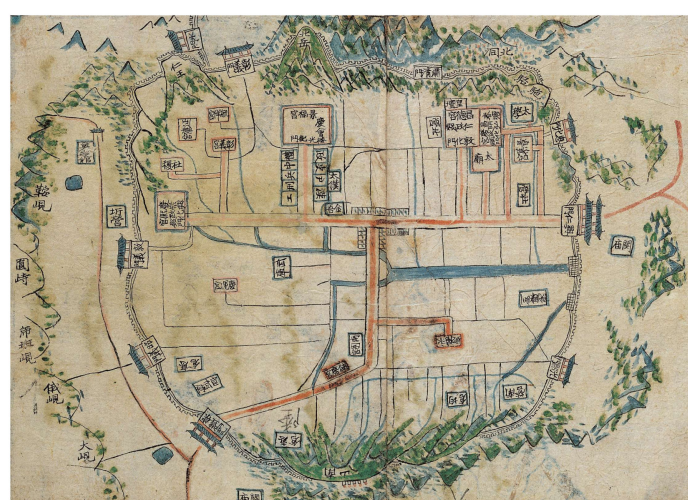

(a)

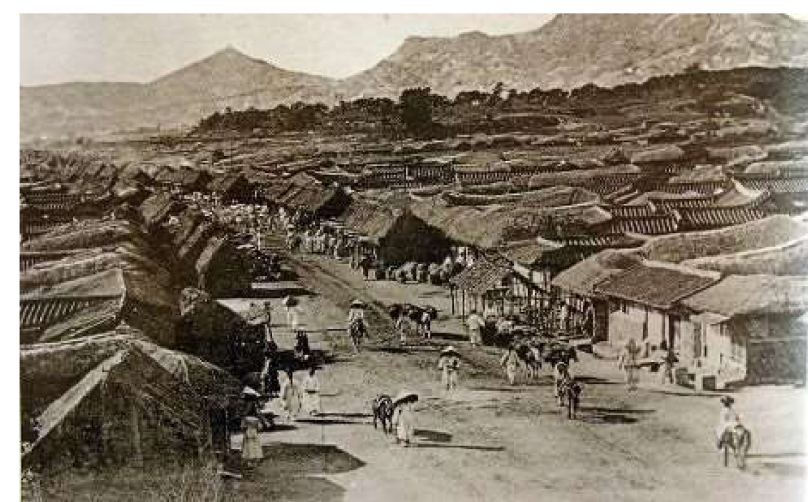

(b)

Figure 4. Jongno of Chosun Dynasty; (a) Map of Seoul in Chosun Dynasty; (b) Photo of Jongno in Chosun Dynasty.

Jongno sustained considerable damage during the Korean War of 1950-53. During post-war restoration, the first and second central land readjustment projects (1952) reorganized the areas surrounding Gwanchul-dong, Jongno 2-ga, parts of Gwansu-dong, Jongno 5-ga, and part of Yeji-dong into today's grid pattern of streets and lots. Even in the 1960s, the central commercial area in Seoul was located in Myeong-dong. During the period of rapid modernization and urbanization in the 1960s, reinforced concrete buildings with six or seven stories became common for new construction in the Jongno area, replacing the two- or three-story masonry buildings constructed in the 1950s. Therefore, the streetscape of Jongno changed along with the modernization of the 1960s [3]. Structurally, the Jongno roadside included stores with a mixture of living spaces, workshops, restaurants, bars, and inns behind them. Workshops mainly produced consumables such as clothes, shoes, bags, jewelry, and so on. This city structure demonstrates tradition passed down from the Joseon era.

In the 1970s, when the national economic system shifted from light to heavy industries, headquarters for the large conglomerates leading the heavy industries began to be constructed around Jongno 1-ga and Seorin-dong. Large-scale lot and high-rise building clusters began to form during this period. In addition, construction of subway line 1 following Jongno in 1974 increased the floating population as a city center. Development of the Gangnam region (areas south of the Han river), starting in the 1970s, and the associated restriction policy targeting Gangbuk (areas north of the Han river, including Jongno), led to decline of the Jongno region. Ultimately, aside from the areas around Jongno 1-ga with high-rises, Jongno's regions began to grow outdated, and this condition worsened into the 1980s.

From that time until the present, with the exception of certain areas, Jongno has grown ever more outdated, and the commercial areas of the city center have continued to lose power. Beginning in the 2000s, the old city structure and outdated buildings were replaced by large-scale lot and high-rise buildings due to redevelopment of the Shinmunno 1-ga, Jongno 1-ga, Cheongjin-dong, and Gongpyeong-dong areas. Excluding the renovation of Seun Sangga Arcade, conducted in the interest of urban regeneration, Jongno maintains the typical form of an original, outdated city center. Despite this, Jongno is central to the Gangbuk region, each of its regions maintains its own specialized commercial areas, and most importantly, it retains its functions and symbolism as a city center for politics, administration, history, and culture that have endured for 600 years.

Overall, Jongno's greatest advantage as a city center following the founding of the Joseon dynasty was its location in the actual center of the city. The flow of information for the entire city is therefore concentrated here, and the business environment, including the proximity of manpower, is set up to conduct major business functions, along with historical, cultural, and leisure facilities. City centers are characterized by centrality due to their various facilities and activities, and the city's residents signify and symbolize this: 
Centrality describes the action of a central element in its periphery. It was defined thus as a hierarchical concept between service and attraction by W. E. Christaller back in 1933 . The attractiveness and circulation of this element is based on the efficacy of the central pole and its accessibility. This element may be an urban centre or a more specialist polarizing element (a shopping, cultural, financial, or administrative centre). Accessibility is a fundamental condition [13].

All symbolize a center with a long historicity and "placeness." The gathering of these various commercial areas gives Jongno an impression of "hybridity," in which different generations meet, different groups gather, and a variety of cultural and commercial activities blend [14]. However, the regions are also considered unsafe with respect to fire or crime, as the streets and buildings are over 50 years old, mostly aged and weathered, and densely situated.

\subsection{Current Commercial Regions of Jongno, and Others}

Even at present, the Jongno region serves as a city center appropriate for light industry, handicrafts, and the service industry. It preserves the commercial city structure started in the Joseon era and has sustainability value in that each region within Jongno has a unique business area and culture. Some areas have been entirely re-developed into new central business areas, while maintaining historical value and regionality. Shinmunno 1-ga is now a street of high-rise buildings for business facilities and high-end hotels. The neighborhood commercial facilities that still exist on the roadsides to the north have renovated and replaced their outdated façades. Overall, the region was redeveloped into a central business region, such as the nearby Integrated Government Building, embassies, and the high-rise business facilities of Seorin-dong.

The northern roadside of Jongno 1-ga and Cheongjin-dong was to maintain the function and form of the old Pimatgol and small-scale restaurants: The structure and neighborhood commercial facilities were incorporated into the lower floors of large roadside buildings, but the old placeness has been lost (Figure 5).

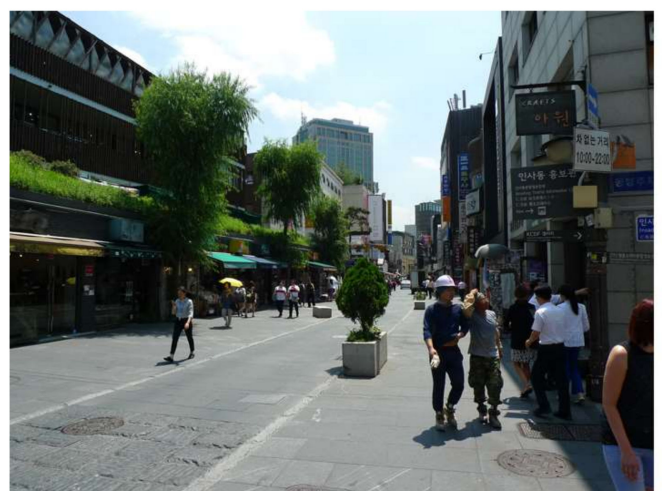

(a)

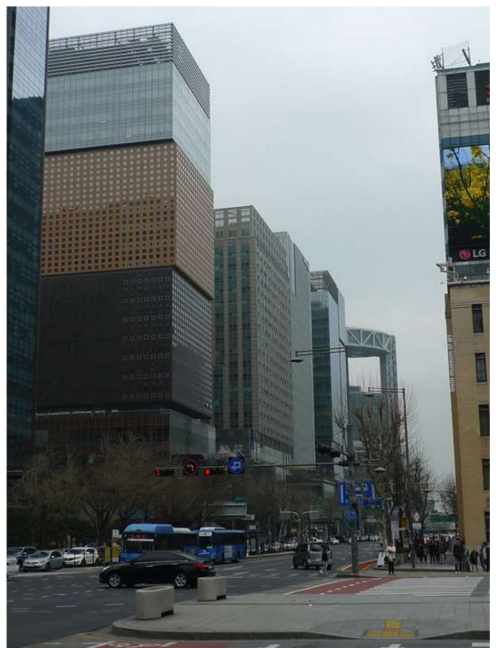

(b)

Figure 5. Streets and buildings in Gwanhum-dong, Insa-dong, Jongno 1-ga and Cheongjin-dong. (a) Small scale buildings and streets in Gwanhum-dong, Insa-dong considered as a traditional area;

(b) High-rise building clusters with large-scale lot, constructed following redevelopment of the northern roadside of Jongno 1-ga and Cheongjin-dong.

The roadside of Jongno 2-ga is the most representative hybrid commercial region in Jongno. This area includes various small facilities such as restaurants, cafes, hearing aid sellers, employment offices, jewelry wholesalers, clothing stores, hospitals, overseas study agents, YMCA buildings, and religious facilities. Excluding the YMCA buildings, which are eight floors high, the structures are two- 
to three-story or four-to-seven-story roadside commercial buildings. Buildings with façades as varied as businesses form the streetscape (Figure 6).

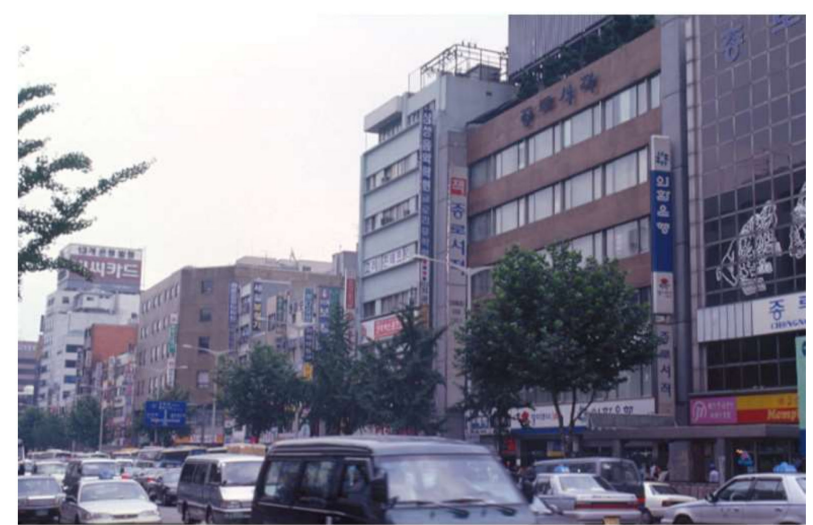

(a)

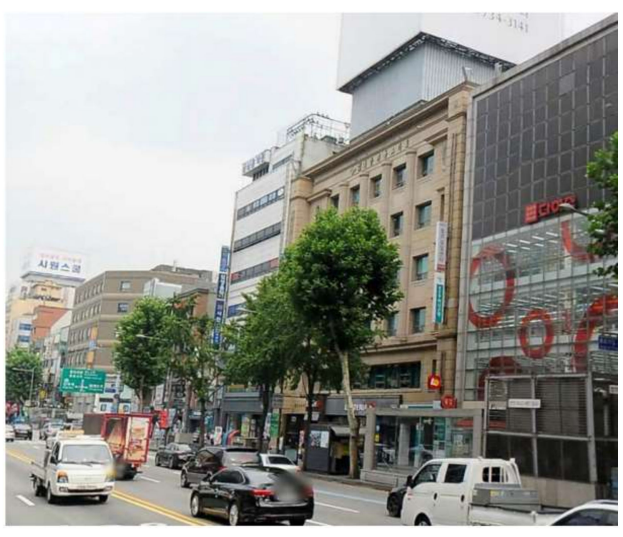

(b)

Figure 6. The landscape of Jongno 2-ga's southern roadside; (a) Taken in 1996, remained the original façades built between 1960s-80s; (b) Taken in 2018, several buildings renovated.

The Insa-dong and Gwanhun-dong area, connected to the north of Jongno 2-ga, is a tourist area considered a traditional street. Antique art stores, antique book stores, antique stores, traditional tea houses, and traditional Korean bars have been located there since long ago, and the place is becoming more and more commercialized as the number of tourists increases. The area is representative of historicity and placeness, and small-scale neighborhood commercial facilities renew their buildings through renovation; however, new construction of large-scale commercial buildings divided into small-scale masses within large-scale land is disrupting the regional coherence (Figure 5).

The Gwanchul-dong region has grid-patterned road systems. As an entertainment area, the place has a high concentration of overseas study agents, private education academies, restaurants, and bars. There are clusters of two- to three-story or six- to seven-story neighborhood commercial buildings (Figure 7).

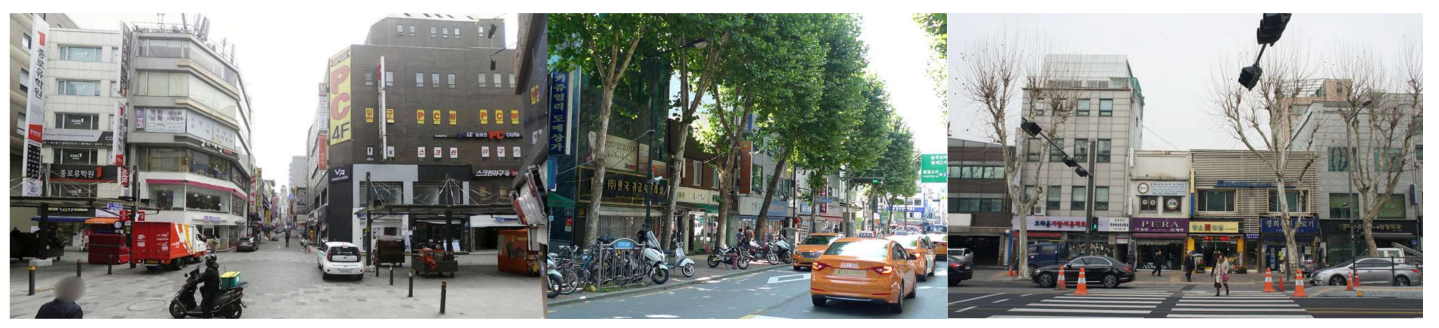

(a)

(b)

(c)

Figure 7. Streets and buildings in Gwanchul-dong, Myo-dong, Jongno 5-ga: (a) Gwanchul-dong as entertainment area; (b) Jewelry store buildings in Myo-dong; (c) Small hospital and medical businesses store buildings in Jongno 5-ga.

The Myo-dong region is the northern region of Jongno 3-ga, located near the jewelry arcade region of Bongik-dong, with a concentration of jewelry arcades and neighborhood commercial facilities (Figure 7). Waryong-dong to the north of that includes traditional instrument stores, traditional Korean clothing stores, mounters, antique art restoration workshops, hostels, and others on its roadsides. It is close to both the antique arts and antiques streets of Insa-dong and to Changdeokgung Palace Donhwamun Gate to the north, and thus is a specialized street handling products related to tradition.

The most representative building of Jongno 3-ga is the Seun Sangga Arcade. A multipurpose building constructed in 1968 on top of a street, it is an arcade specialized in electrics and electronic 
products. Although it is responsible for wholesale distribution through its connection with the nearby mechanical part and tool arcades. As of recently, it is undergoing an urban regeneration process.

Jongno 5-ga and 6-ga have grid-patterned structures. The commercial area consists of warehouse type clothing stores built in the 1950s-60s, and the place has a concentration of pharmacies, oriental medicine hospitals, oriental medicine supply stores, and pesticide and seedling stores. These commercial areas formed due to the geographic proximity to the outskirts of the city, close to the easternmost point of Jongno. Currently, the outdated buildings maintain their story elevations, but do conduct remodeling through façade renovation (Figure 7).

In Jongno, the various areas have historical regionality and identity, as well as heritage value. This is because their value extends from the traditional culture of the Joseon era to the legacy of modern industry development and culture.

\section{Formal Analysis of Façade Renovation}

\subsection{Locational Distribution of and Stores Occupying the Example Structures}

The 41 buildings investigated were neighborhood commercial facilities. Examples were investigated in Shinmunno 1-ga (three buildings), Gwanhun-dong (one), Gwanchul-dong (four), Jongno 2-ga (four), Myo-dong (three), Waryong-dong (two), Jongno 3-ga (two), Jangsa-dong (two), Yeonji-dong (one), Ihwa-dong (one), Inui-dong (one), Hyoje-dong (two), and Jongno 5-ga (11). Eleven buildings in Jongno 5-ga had undergone façade renovation.

This implies that the region has many buildings that were built in the 1950s-60s, and the fact that so many buildings were renovated rather than torn down and newly built identifies it as a representative area of low investment in real estate. The investigated buildings in Jongno 5-ga were in commercial areas containing pharmacies, hospitals, oriental medicine hospitals, oriental medicine supply stores, wholesale clothing stores, and pesticide and seedling stores. The stores occupying the eleven buildings included various clothing wholesalers, oriental medicine hospitals, hospitals, pharmacies, medical equipment stores, coffee shops, car dealerships, flower shops, fortune tellers, dance academies, beauty parlors, employment agencies, and so on. Both stores related to the regional commercial area and employment agencies and similar businesses, showing the demand for labor in the neighborhood commercial area and region, occupied the buildings.

Four buildings were investigated in Gwanchul-dong, traditionally an entertainment region with many restaurants, bars, private educational academies, and so on. These buildings contained overseas study agents, ice cream stores, bars, restaurants, gosiwons (one-room residences), motels, small general stores (supermarkets), and so on. In Jongno 2-ga, with commercial areas of hybridity, four buildings were investigated. Various types of stores occupied the buildings, such as jewelry stores, hearing aid stores, cafés, music academies, Pilates academies, and so on. The two investigated buildings in Jongno 3-ga, which has characteristics like Jongno 2-ga, also contained jewelry stores, as well as traditional Korean clothing stores, employment agencies, realtors, and so on. The three buildings investigated in Myo-dong contained jewelry stores, acupuncture services, bars, and so on; the two buildings investigated in Waryong-dong housed supermarkets, hostels, mounters, antique art workshops, traditional Korean clothing stores, and so on. Examining the types of stores occupying the investigated buildings shows that mix between buildings with stores matching the characteristics of the region's commercial area and buildings with neighborhood commercial facilities or business facilities (Table 1) (Figure 8). 
Table 1. Change in stores occupying the investigated buildings.

\begin{tabular}{|c|c|c|c|c|}
\hline Region & No. of Buildings & Before Façade Renovation & $\begin{array}{c}\text { Currently (after Façade } \\
\text { Renovation) }\end{array}$ & Characteristics \\
\hline Jongno 5-ga & 11 & $\begin{array}{l}\text { Pharmacy, employment office, } \\
\text { oriental medicine hospital, } \\
\text { shoe store, golf store, bar, } \\
\text { sewing machine store, sewing } \\
\text { services, mountain climbing } \\
\text { equipment }\end{array}$ & $\begin{array}{l}\text { Hospital, hair salon, car } \\
\text { dealership, medical } \\
\text { equipment store, flower } \\
\text { shop, accounting firm, } \\
\text { pharmacy, employment } \\
\text { office, café, private } \\
\text { educational academy, tent } \\
\text { wholesaler, etc. }\end{array}$ & $\begin{array}{l}\text { Many medical businesses } \\
\text { and stores related to } \\
\text { clothing, such as clothing } \\
\text { wholesalers }\end{array}$ \\
\hline Gwanchul-dong & 4 & $\begin{array}{l}\text { Pharmacy, overseas study } \\
\text { agent, inn, restaurant, } \\
\text { supermarket, pool hall, coffee } \\
\text { shop, clothing store, café, } \\
\text { video room }\end{array}$ & $\begin{array}{l}\text { Overseas study agent, nail } \\
\text { salon, inn, restaurant, } \\
\text { supermarket }\end{array}$ & $\begin{array}{l}\text { Many entertainment } \\
\text { service businesses, such as } \\
\text { inns and overseas studies } \\
\text { agents }\end{array}$ \\
\hline Jongno 2-ga & 4 & $\begin{array}{l}\text { Hearing aid seller, glasses } \\
\text { store, restaurant, hospital, } \\
\text { karaoke, video room, clothing } \\
\text { store, coffee shop }\end{array}$ & $\begin{array}{l}\text { Jewelry store, hearing aid } \\
\text { store, gym, café, nail salon, } \\
\text { music academy }\end{array}$ & $\begin{array}{l}\text { Many hearing aid stores, } \\
\text { medical businesses, } \\
\text { jewelry stores, and } \\
\text { entertainment services }\end{array}$ \\
\hline Jongno 3-ga & 2 & $\begin{array}{l}\text { Restaurant, employment } \\
\text { office, gym, hospital }\end{array}$ & $\begin{array}{l}\text { Jewelry store, employment } \\
\text { office, realtor }\end{array}$ & $\begin{array}{l}\text { Many jewelry stores and } \\
\text { employment offices }\end{array}$ \\
\hline Myo-dong & 3 & $\begin{array}{l}\text { Restaurant, overseas study } \\
\text { agent, photography goods, } \\
\text { measuring instruments store, } \\
\text { acupuncture clinic }\end{array}$ & $\begin{array}{l}\text { Jewelry store, convenience } \\
\text { store, restaurant, hospital }\end{array}$ & Many jewelry stores \\
\hline Waryong-dong & 2 & $\begin{array}{l}\text { Supermarket, coffee shop, } \\
\text { textbook store, photography } \\
\text { goods }\end{array}$ & $\begin{array}{l}\text { Supermarket, café, hostel, } \\
\text { restaurant, mounter, } \\
\text { Korean traditional clothing } \\
\text { store }\end{array}$ & $\begin{array}{l}\text { Many antique arts, } \\
\text { traditional Korean } \\
\text { clothing, and service } \\
\text { industry stores }\end{array}$ \\
\hline Gwanhun-dong & 3 & $\begin{array}{l}\text { Oriental medicine hospital, } \\
\text { inn, medical equipment, } \\
\text { restaurant, book store }\end{array}$ & $\begin{array}{l}\text { Motel, handicraft gallery, } \\
\text { antiques store, antique } \\
\text { book store, café }\end{array}$ & $\begin{array}{l}\text { Many antique book, } \\
\text { antique, service industry, } \\
\text { and medical industry } \\
\text { stores }\end{array}$ \\
\hline Shinmunno 1-ga & 3 & $\begin{array}{l}\text { Restaurant, hospital, } \\
\text { pharmacy }\end{array}$ & $\begin{array}{l}\text { Restaurant, clothing store, } \\
\text { pharmacy, hospital }\end{array}$ & $\begin{array}{l}\text { Many medical industry } \\
\text { entities, such as hospitals } \\
\text { and pharmacies }\end{array}$ \\
\hline Jangsa-dong & 2 & $\begin{array}{l}\text { Machine seller, electronics } \\
\text { store }\end{array}$ & $\begin{array}{l}\text { Machine seller, electronics } \\
\text { store }\end{array}$ & $\begin{array}{l}\text { Many stores in the } \\
\text { machinery and electronics } \\
\text { field }\end{array}$ \\
\hline Hyoje-dong & 2 & $\begin{array}{l}\text { Oriental medicine hospital, } \\
\text { dentist, office, employment } \\
\text { office }\end{array}$ & $\begin{array}{l}\text { Oriental medicine hospital, } \\
\text { dentist, office, realtor, } \\
\text { service industry }\end{array}$ & $\begin{array}{l}\text { Many small-scale offices in } \\
\text { the medical field }\end{array}$ \\
\hline Other & 5 & & & \\
\hline
\end{tabular}

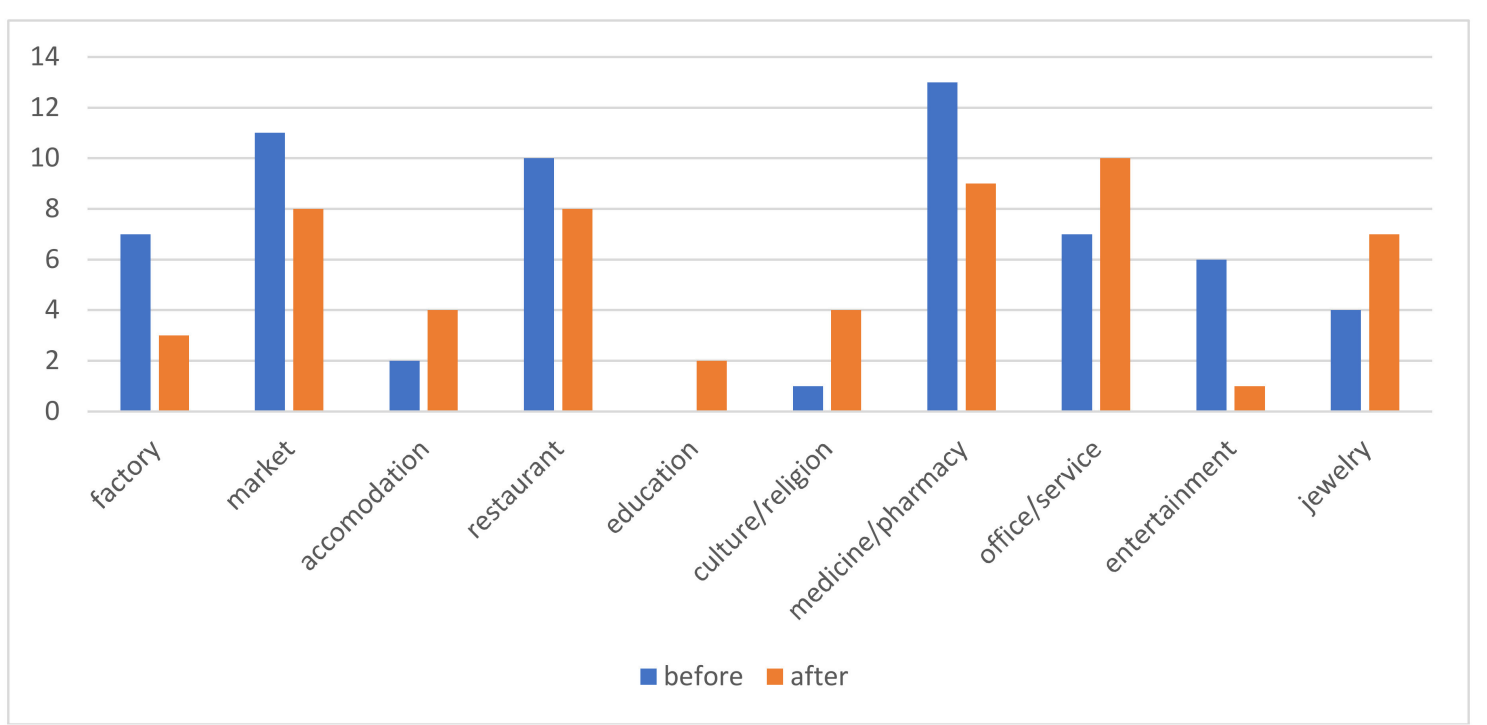

Figure 8. Change in stores occupying the investigated buildings. 


\subsection{Type Analysis of Façade Renovation}

When renovating an aged façade, past, present, or future conditions are considered. Designs may be limited, or may have to conform to conditions based on the structure and façade of the original building. New façade designs and materials may be popular, and a certain commercial image is meant to be expressed. Therefore, it was necessary to determine the original state of the buildings that underwent façade repair. The 161 buildings of the precedent study, which were newly built in the 1950s-60s, were broadly categorized into three types based on period: Mid 50s-Late 50s, Late 50s-Mid 60s, Mid 60s-Late 60s. The main structuring methods used during these three periods changed from masonry to mixed masonry/reinforced concrete to reinforced concrete, and the height of the buildings increased accordingly from two- to three-story to three- to five-story to five- to six-story (Table 2) (Figure 9). Changes in structuring methods led to change in façade design. Masonry structures were characterized by uneven wall designs and tile finishing. This demonstrated modeling intent through unevenness and wall shading, as structural limitations prevented large openings. Mixed masonry/reinforced concrete structures mostly had vertical bands, slab-protruding bands, and so on finished with tile or cement mortar, the façade design popular at the time. Reinforced concrete structures have many horizontal windows, increased widow area, and tile or exposed concrete finishing. The new material made horizontal windows structurally possible, and consequently, wide façade designs to fit the large openings became common. An examination of the 41 original buildings that were renovated, noting their original structure, number of floors, and façade design, reflects the categorization of these three types by period

Table 2. Structure type, number of floors, and construction year of the investigated buildings.

\begin{tabular}{|c|c|c|c|c|c|c|c|c|c|c|c|c|c|c|c|}
\hline Structure & $\begin{array}{l}\text { No. of } \\
\text { Floors }\end{array}$ & ‘54 & ‘55 & ‘56 & ‘57 & ‘60 & ‘61 & ‘63 & ‘64 & ‘65 & ‘66 & ‘67 & ‘68 & ‘69 & Total \\
\hline Wood & 2 & 1 & & & & & & & & & & & & & 1 \\
\hline \multirow{2}{*}{ Masonry } & 2 & & 1 & 1 & 2 & & 1 & 1 & & & & & & & 6 \\
\hline & 3 & & & 1 & 1 & & & & & 1 & & & & & 3 \\
\hline \multirow{5}{*}{$\begin{array}{c}\text { Mixed } \\
\text { masonry/reinforced } \\
\text { concrete }\end{array}$} & 3 & & & & & & & 1 & & 1 & & & & & 2 \\
\hline & 4 & & & & & & & & & 1 & & 1 & & & 2 \\
\hline & 5 & & & & & & & 1 & & 1 & & 1 & & & 3 \\
\hline & 6 & & & & & & & & & 1 & & 1 & & & 2 \\
\hline & 7 & & & & & & & & & 1 & & 1 & & & 2 \\
\hline \multirow{4}{*}{$\begin{array}{l}\text { Reinforced } \\
\text { concrete }\end{array}$} & 3 & & & & & & & & & & & & & 1 & 1 \\
\hline & 4 & & & & & & 2 & & 1 & 1 & 3 & & 1 & 1 & 9 \\
\hline & 5 & & & & & 1 & & & & 2 & 2 & & 1 & 3 & 9 \\
\hline & 7 & & & & & & & & & & & & 1 & & 1 \\
\hline Total & & 1 & 1 & 2 & 3 & 1 & 3 & 3 & 1 & 9 & 5 & 4 & 3 & 5 & 41 \\
\hline
\end{tabular}

The two- to three-story masonry buildings were mainly located in Jongno 5-ga. Because the existing commercial areas for clothing wholesalers, pharmacies, oriental medicine hospitals, and pesticides and seedling stores were maintained, new high-rise construction did not occur; the low-story buildings were renovated and used. Mixed masonry/reinforced concrete buildings and the reinforced concrete buildings were shown to be distributed evenly across areas.

Trends for the investigated façade renovations show that the condition of the original façade design had a great impact on the renovation. We identify three categories in which the façade renovations were completely different, partly different, and similar to the original façade, respectively. Based on these three categories, we explain the original façade form, the structural form, the current commercial usage of the building, and other characteristics. 


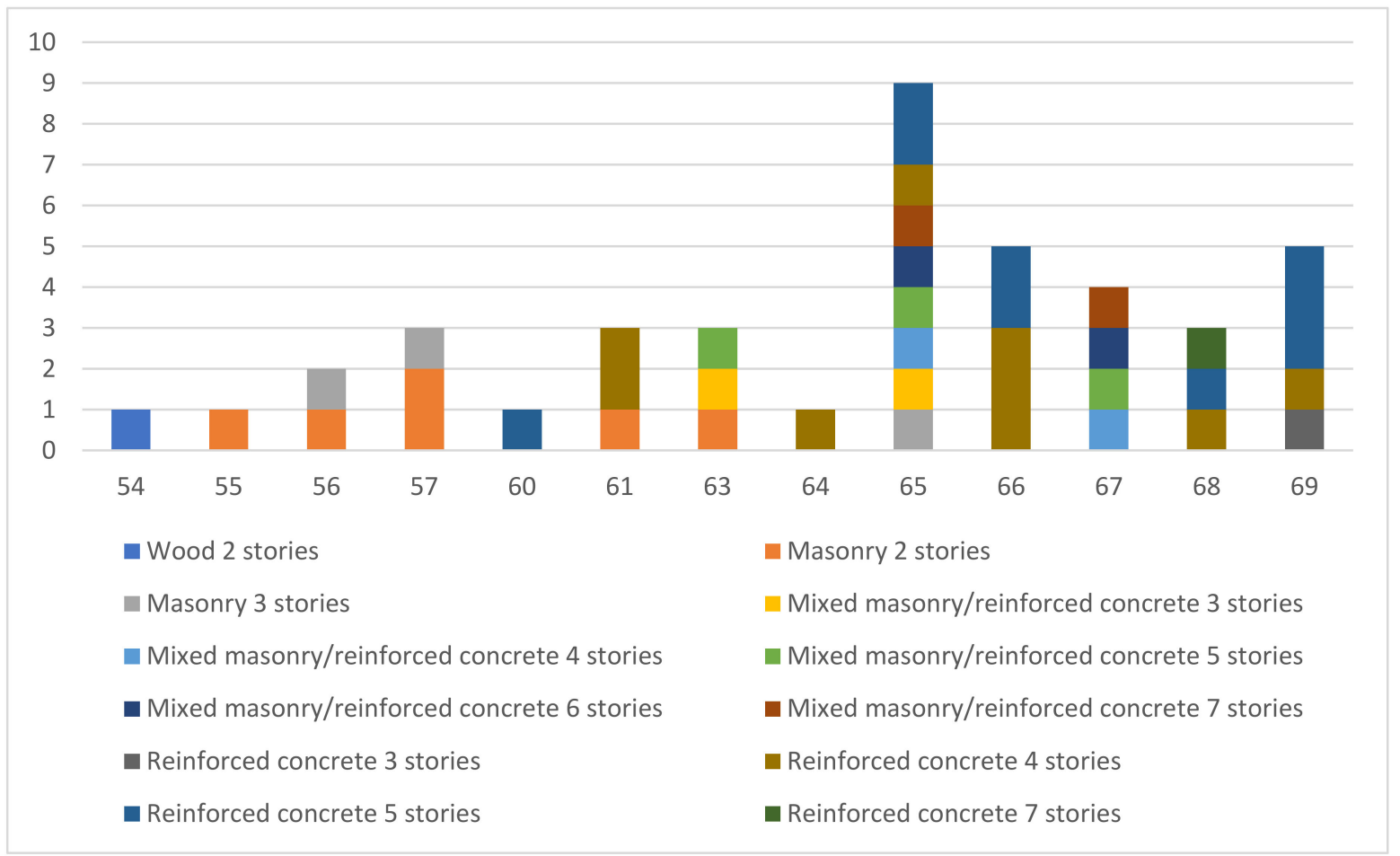

Figure 9. Structure type, number of floors, and construction year of the investigated buildings.

First, renovations that are completely different from the original façade are cases in which the existing façade was torn down or covered by a completely different façade design. A total of 12 buildings fell into this category (Table 3) (Figure 10). Seven of the 12 had original façade designs using vertical bands, horizontal bands, unevenness, and so on; these were completely torn down or covered by a different façade design in the renovation. In particular, buildings with vertical bands used a façade design that was widely applied to mixed masonry/reinforced concrete and reinforced concrete buildings and in the early to mid-1960s. Many vertical bands were finished with tiles or cement mortar with a modeling intent. Examples of this are Gwanchul-dong 44-1 (61), Jongno 2-ga 84-10 (60), and Jongno 5-ga 332-6 (65). The original decorations looked behind the times, and because from an execution standpoint the narrow width of the unevenness is difficult to renovate, the existing decorations were completely torn down and finished with curtain walls or panels, or alternately completely covered by panels, to create a completely new opening form and façade design. Gwanchul-dong 44-1 tore down the vertical bands and aimed to completely expose the interior to the exterior using glass curtain walls and panels. Jongno 2-ga 84-10 tore down the original vertical bands, created larger openings, and used a salmon-colored stone for finishing, for a space occupied by a Starbucks coffee shop. Jongno 5-ga 332-6 also completely covered the original narrow-width vertical bands with panels to create a façade completely different from before (Figure 11). Additionally, these façade renovations that are completely different from the original seem to be related to the regional commercial area. Shinmunno 1-ga 135-2 (68) completely removed the original façade of horizontal windows and replaced it with a façade of metal and glass curtain walls. This choice was presumably made to avoid lagging behind in the newly cultivated atmosphere of the street created by new construction of high-rise business facilities and high-end hotels. Jongno 5-ga 321-25 (54) is located in a clothing wholesale commercial area, and so was finished with black panels to present a unified brand image for BlackYak. Renovations that are completely different from the original façade entirely move away from past façade design trends that were popular before and paint a new commercial image. Nevertheless, it can be seen that scales and programs originating from building structures and floors continue. 
Table 3. Façade material for renovations vs. original façade design.

\begin{tabular}{|c|c|c|c|c|c|c|c|c|c|c|c|}
\hline $\begin{array}{c}\text { Façade } \\
\text { Renovation Type }\end{array}$ & $\begin{array}{l}\text { New Façade Material } \\
\text { Original Façade Design }\end{array}$ & Stone & Panel & $\begin{array}{c}\text { Curtain } \\
\text { Wall + Panel }\end{array}$ & Steel & Brick & $\begin{array}{l}\text { Brick }+ \\
\text { Panel }\end{array}$ & $\begin{array}{c}\text { Panel + } \\
\text { Wood }\end{array}$ & Wood & $\begin{array}{l}\text { Dry } \\
\text { Vit }\end{array}$ & Total \\
\hline \multirow{4}{*}{ A } & Vertical bands & 1 & 2 & 1 & & & & & 1 & & 5 \\
\hline & Uneven walls & & & 1 & 1 & & & & & & 2 \\
\hline & Horizontal windows & & & 3 & & & & 1 & & & 4 \\
\hline & Other & & 1 & & & & & & & & 1 \\
\hline \multirow{3}{*}{ B } & Uneven walls & 5 & & & & & & & & & 5 \\
\hline & Horizontal windows & 1 & 3 & & & 1 & 2 & & & & 7 \\
\hline & Other & 2 & 1 & & & & & & & & 3 \\
\hline \multirow{4}{*}{ C } & Vertical bands & 1 & & & & & & & & & 1 \\
\hline & Horizontal windows & 7 & 2 & & 1 & & & & & 1 & 11 \\
\hline & Other & & & & 1 & & & & 1 & & 2 \\
\hline & Total & 17 & 9 & 5 & 3 & 1 & 2 & 1 & 2 & 1 & 41 \\
\hline
\end{tabular}

A: Completely different from original façade; B: Partly different from original façade; C: Similar to original facade.

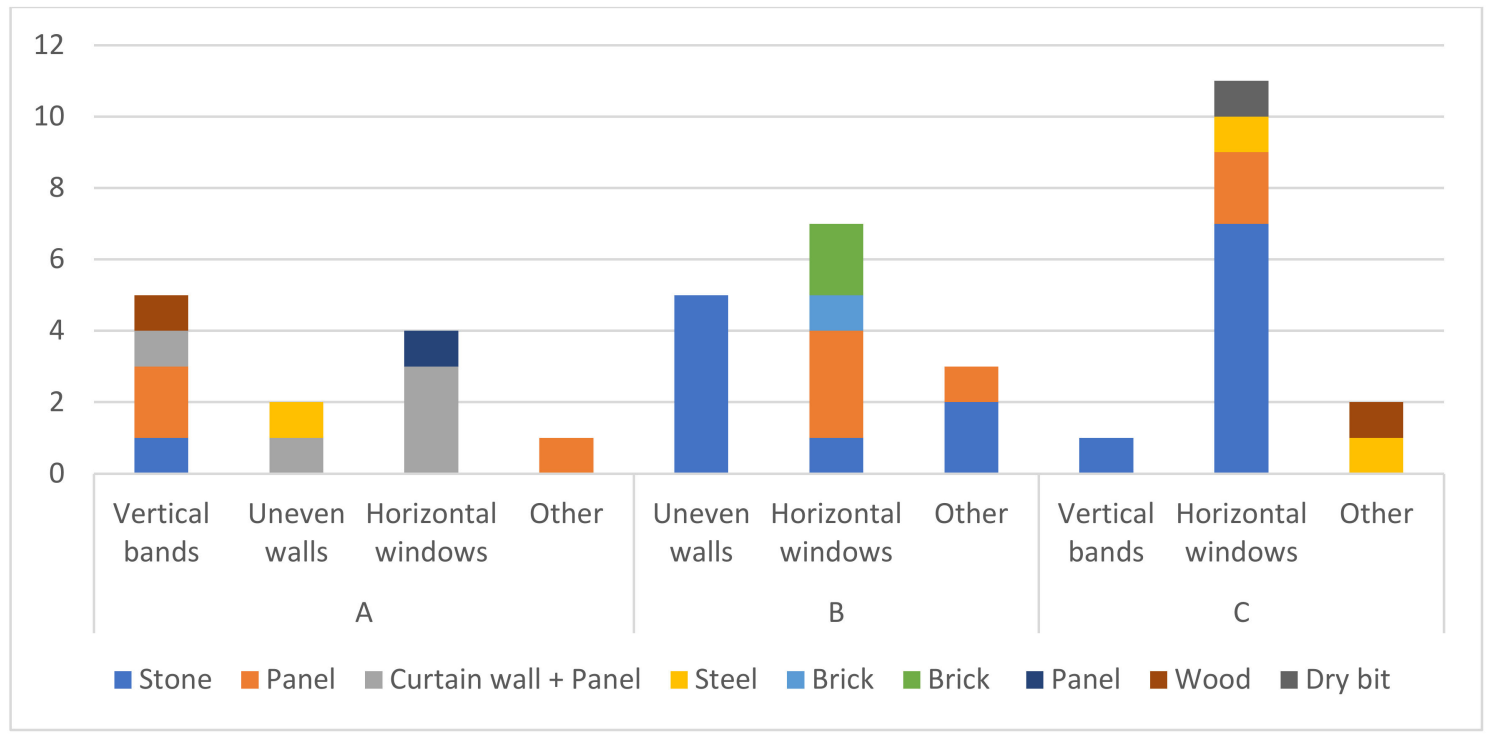

Figure 10. Façade material for renovations vs. original façade design.

A total of 15 buildings had renovations partly different from the original façade (Table 3) (Figure 10). Partly different means cases in which uneven walls were covered and hidden, but the openings were left in their original form, or cases in which some of the opening forms were changed, leading to change in façade material. Masonry buildings constructed in the late 50s to mid-60s added unevenness to walls and finished with tiles. As these buildings were renovated, the outdated tile finishing and wall unevenness were hidden using stone or metal frames, but the openings were maintained. Therefore, facades were primarily finished using polished stone on the uneven and tiled walls. The Jongno 5-ga 12 building, a masonry structure with an uneven façade, had its openings preserved as they were, but the entire façade was finished with stone. An oriental medicine hospital occupied the space in 2001; it is now occupied by an orthopedic hospital.

Eight reinforced concrete buildings of 15 buildings that were partly different from the original façade originally had facades divided by horizontal or wide windows, with openings divided into regular intervals or clearly expressed in stepped portions; such openings were partially changed. In addition, six of the buildings were finished using red-toned decorative brick, stone, and panels. The Hyoje-dong 298-4 building was typical of building forms in the late 1960s: a reinforced concrete structure with horizontal windows, slightly uneven walls, and exposed concrete finishing. During its renovation, the façade material was covered by panels, whereas the opening methods were maintained. The building projects the image of a business facility, and its space is occupied by various types of small offices. The Yeji-dong 220 building also maintained its original opening forms while replacing the façade, originally finished with tiles, with panels. It currently functions as a one-room residence building that provides workers with temporary living space in the city center. These buildings use 
panels to cover up uneven walls on some parts of the facades, while maintaining past façades overall, including openings. They are considered to partially reject some decoration of past façades (Figure 12).

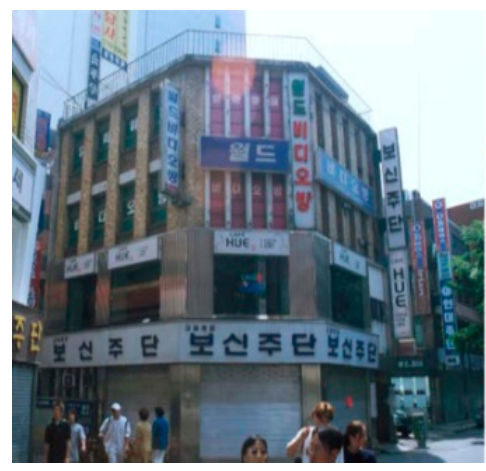

(a)

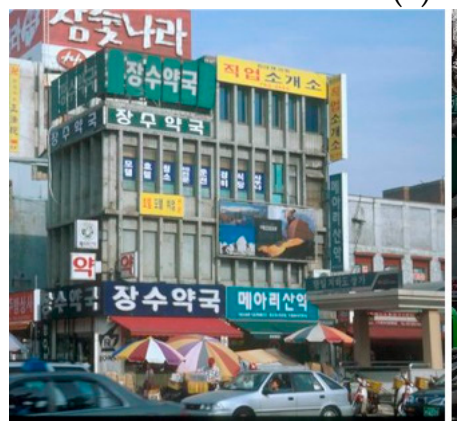

(c)
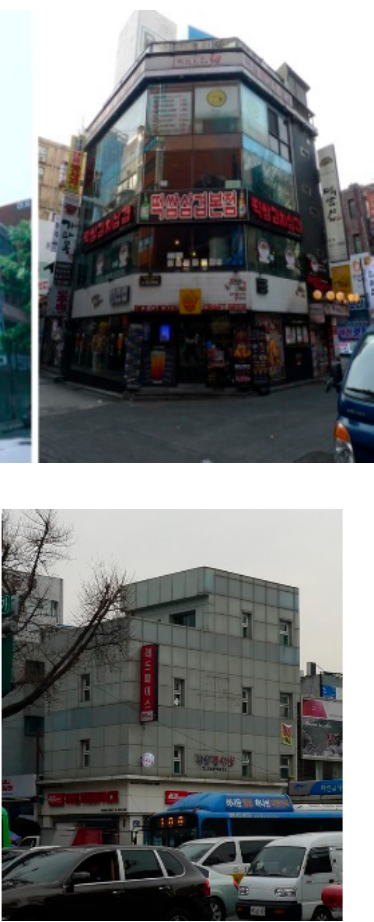
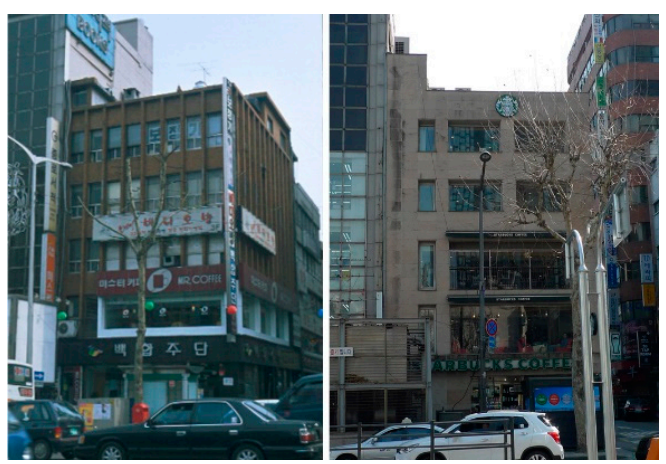

(b)
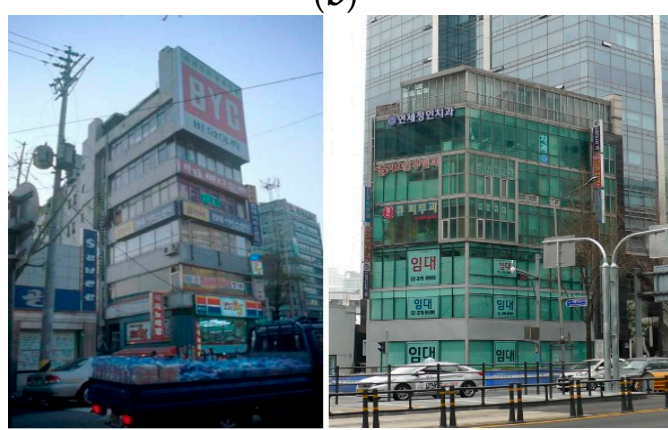

(d)

Figure 11. Before and after façade renovations completely different from the original: (a) Gwanchul-dong 44-1; (b) Jongno 2-ga 84-10; (c) Jongno 5-ga 332-6; (d) Shinmunno 1-ga 135-2
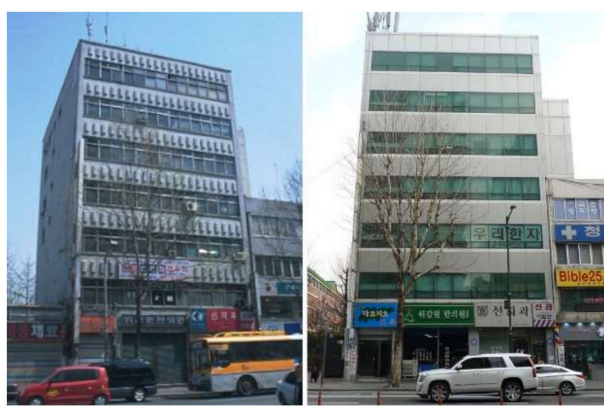

(a)
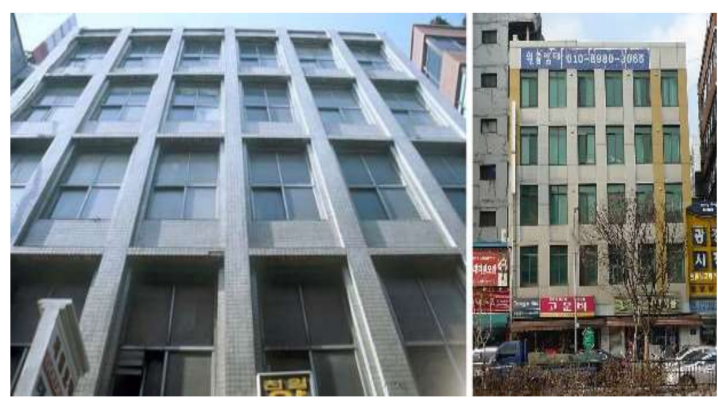

(b)

Figure 12. Before and after façade renovations partly different from original: (a) Hyoje-dong 298-4; (b) Yeji-dong 220.

Overall, 14 buildings were renovated similarly to the original façade (Table 3) (Figure 10). These largely preserved existing openings, while decorations resurfaced the façade with a different material. The 14 buildings included mixed masonry/reinforced concrete structures and reinforced concrete structures built in the mid to late 1960s. These buildings are characterized by relatively wide openings or horizontal windows, and were typically finished with tiles, red brick, and cement mortar. Vertical louvers or unevenness were uncommon, so the renovations maintained the decorations of the existing façade, only replacing the aged façade surface. Most were renovated using stone. The Gwanchul-dong 14-11 building is a mixed masonry/reinforced concrete structure with horizontal windows, originally finished using cement mortar; its façade renovation covered the building with white small panels and maintained the form of the horizontal windows. The building is currently used for recreation and business activities, for example ice cream stores and overseas study agencies. 
Yeonji-dong 174 is a reinforced concrete structure with horizontal windows; its façade renovation replaced the old tile finishing with stone. The building is a typical neighborhood commercial facility with restaurants, coffee shops, and butchers occupying the space. These buildings, whose façades look similar to past façades, mostly maintain the number of floors, programs, façade styles, and decorations (Figure 13).

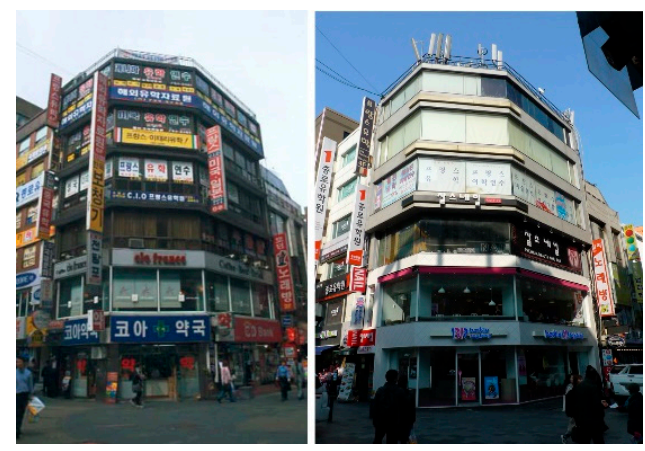

(a)

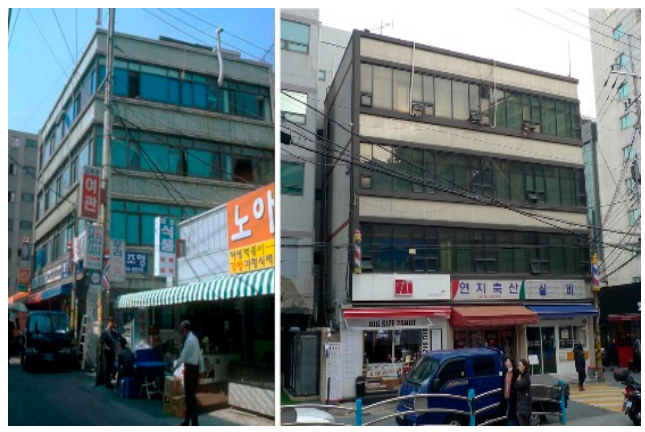

(b)

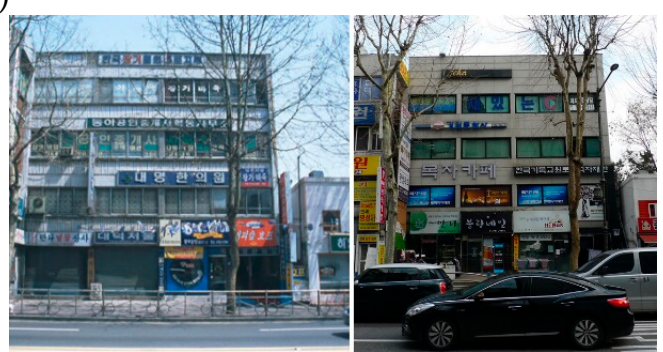

(c)

Figure 13. Before and after façade renovations similar to the original: (a) Gwanchul-dong 14-11; (b) Yeonji-dong 174; (c) Hyoje-dong 301-2.

The most important characteristic of façade renovation is finishing material. Stone, panels, and glass curtain walls were widely used. For cases using stone, the renovation was often similar to or only partially different from the original; in cases using panels or glass curtain walls, the renovation was often at least partly or completely different from the original façade.

\section{Adaptation of Jongno's Roadside Commercial Buildings and Their Sustainability as City Architecture}

\subsection{Adaptation to Changing Times and Sustainability as Urban Architecture}

The primary motive building owners have for façade renovation is profit seeking. In the investigated buildings, the majority of renovations focused only on the exterior façade rather than major structures or the building interior. This is done to redesign an old and aging building, to draw customers and increase store rental fees with minimal investment. Whereas the original façade designs and materials followed the trends of their time, in the current period they have grown outdated. They are neither "dandy" nor vintage, and sometimes significant aging causes people to mistrust and avoid a building. New façade renovation changes the image of the building using the designs and materials popular now. However, use of standardized designs and industrialized materials can project an overly common image.

Examination of the materials used for façade renovation shows that tiles and cement mortar, common finishing materials in the 50s-60s, were replaced with stone, panels, glass, and steel. Of those, stone and panels are the standardized façade materials that can be most easily implemented in the modern period. Selection of such materials is an important factor in determining the image of a building. 
In many cases, renovations using panels and glass curtain walls as façade materials were partly or completely different from the original. These cases include the buildings of Shinmunno 1-ga 31, Yeji-dong 220, Jangsa-dong 204, and Hyoje-dong 298-4, which tried to express an image corresponding to their facilities. Shinmunno 1-ga 31 and Hyoje-dong 298-4 are small-scale office rental buildings, and Jangsa-dong 204 is a bank branch, which attempted to express a modern bank business image by using opaque glass. The buildings that used glass curtain walls include Gwanchul-dong 44-1, a bar; curtain walls attempt to entice customers by directly exposing the internal atmosphere of the bar to the exterior. Red brick and panels were also used to convey façade design characteristics in line with each commercial purpose, for example franchise stores. An example is the A Twosome Place coffee shop in the Shinmunno 1-ga 33 building. Rather than using polished stone or shiny glass curtain walls, the renovation featured rough surfaces such as red brick, which conveys the image of age, and black matte panels. This presents a special image of a space to drink tea, rather than a technical image. A Twosome Place coffee shops located all around Korea share this common design aesthetic, branding the façade as a whole to make the business stand out in the streetscape. Thus, franchise brands can be promoted through façade design. Other coffee shops, such as the Coffee Bean, Holy Coffee, and so on, apply their own image to their façades in a similar way. Another case of brand image being added to the façade appears in Jongno 5-ga 321-25. The building, a wood structure constructed in the 1950s, was refinished with black panels to express the brand image of Black Yak, an outdoor clothing brand. By using a common design in its stores, Black Yak aims to promote itself in Jongno 5-ga, a commercial area for clothing wholesalers. These buildings actively display commercial expression through renovated façades, considering occupant stores' characteristics and surrounding contexts (Figure 14).

In some cases, red brick was used to present a vintage image, instead of panels and stone, which present a new image. Such designs are trending in roadside commercial buildings in the Jongno region, including the Jongno 2-ga 19 building, with a façade design using red brick and panels, and the Dangju-dong 2-3 building, a typical neighborhood commercial facility currently housing restaurants, bars, yoga academies, and so on, finished with decorative bricks in a light red color. The use of light red in particular was intended to convey an old-looking but stable atmosphere. Commercial buildings purposely presenting a vintage image is a trend currently found in many regions of Jongno (Figure 14).

Renovations using stone as the façade material were frequently similar to or partly different from the original façade. There are many reasons to renovate a façade similarly to the original. First, if the original façade design includes horizontal windows (or sufficient opening area) and horizontal bands, the openings and façade design are not considered outdated (in comparison to designs incorporating vertical louvers or uneven walls). Second, identity can be changed by resurfacing with a different material, which is cheaper than tearing down the entire original façade and constructing curtain walls. In the case of Gwanhun-dong 147, an interview was conducted with a first-floor seller of antique books. The owner of this bookstore also owned the building. The owner stated that they selected the cheapest renovation materials for economic reasons. Grooved pillar decorations, imitating the pillars of ancient Western architecture, were created using dryvit on the wall. Nevertheless, the aim was to create a classical atmosphere, borrowing from ancient Western architecture at a low cost in the Gwanhun-dong region, while referencing a traditional Korean street. This case illustrates the Korean way of borrowing Western architecture decoration, or kitsch, an example of cultural hybridity (Figure 15). Third, ordinary neighborhood commercial facilities do not need to express specific commercial needs through their façade, or leaving the old façade as it is may be better for regular customers. In such cases, there is no need to pursue a completely different façade design using materials such as panels or curtain walls. The choice to renovate an existing façade similarly is probably a combination of these three reasons. This applies to the Gwanchul-dong 14-11, Gwanchul-dong 25, Yeonji-dong 174, and Hyoje-dong 301-2 buildings, which had horizontal windows or large openings and underwent a change in façade material only, using small panels or stone, making the most of the existing façade decorations. The Gwanchul-dong 14-11 building is a recreational and business facility, and the others are common neighborhood commercial facilities in their respective regions. When 
façade renovations similar to the original are conducted, they maintain a great deal of the building's original atmosphere.
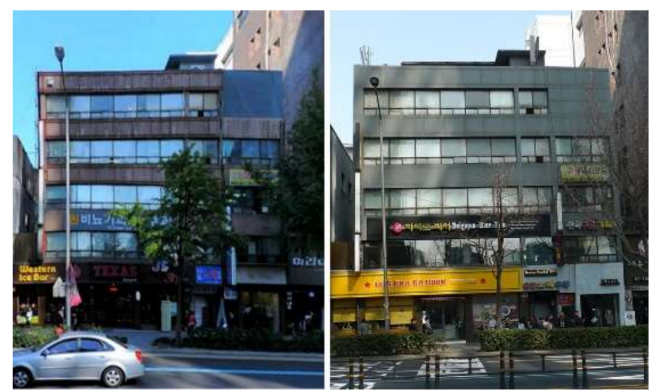

(a)

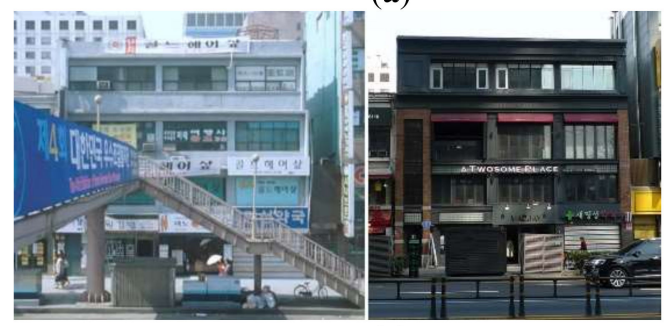

(c)

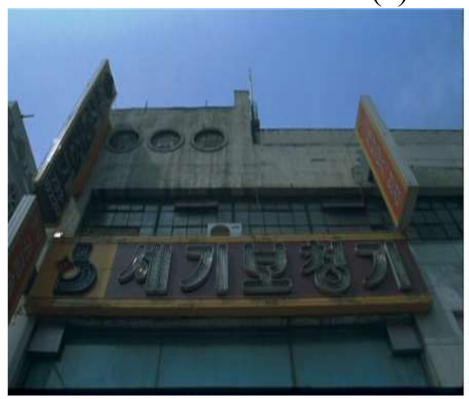

(e)
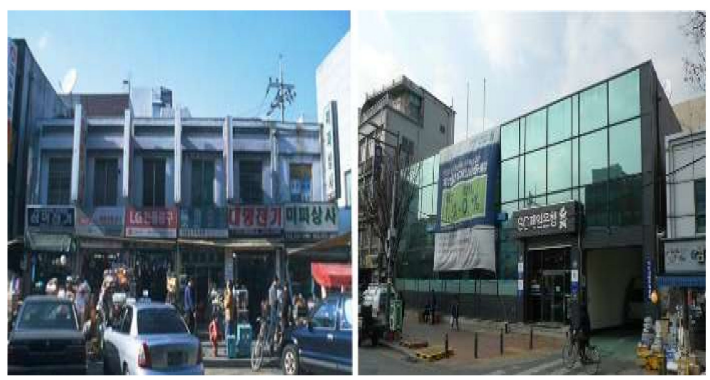

(b)

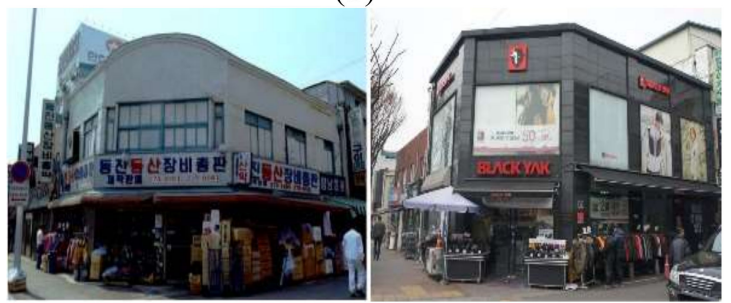

(d)

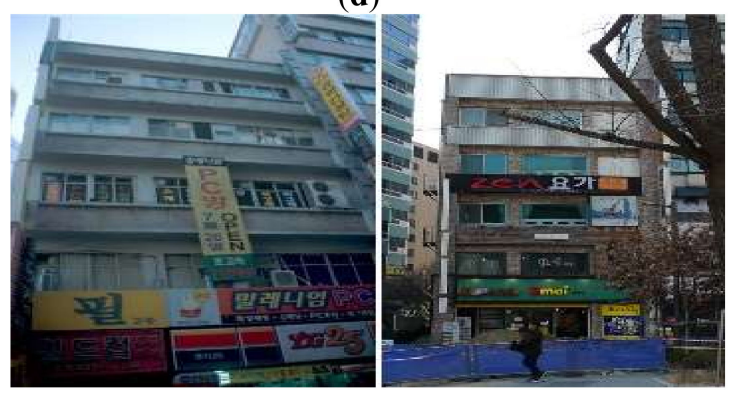

(f)

Figure 14. Commercial expressions through the renovated façades and theirs trends: before and after façade renovations: (a) Shinmunno 1-ga 31; (b) Jangsa-dong 204; (c) Shinmunno 1-ga 33; (d) Jongno 5-ga 321-25; (e) Jongno 2-ga 19; (f) Dangju-dong 2-3.

Renovations that are partly or completely different from the original façade offer the building a new image. A brand image can be added to the entire façade, the façade can expose internal business activities to the exterior, or the façade can present a modern image or follow trends for vintage designs. In such cases, the building's size, height, and use are maintained, but the façade image of the previous generation is rejected, changed, and adapted to meet the new age. This must be accepted as the result of change due to new business trends. Façade renovations also express commercial activities and add something new to the regional streetscape. In renovations similar to the original façade, a great deal of the building's previous image is maintained, along with maintenance of the existing commercial activity, building size, and number of floors. Most buildings newly constructed in the 1960s have horizontal windows and large openings. Preservation of these façade designs, forms of modern architecture that were popular at the time, indicate that the designs are still accepted in the present. In the cases of these three types of façade renovation, commercial activities and the buildings' size, number of floors, general programs for use, and certain original façades are maintained. In these places, merchants and consumers continue to lead their daily lives. Although new commercial activities and façades are added, the combination of the material and immaterial maintain the atmosphere and landscape of each region of Jongno. This shows that the façade of a building has sustainability within the sustainability of commercial activity, and it shows the regionality and sustainability of urban architecture within the streetscape of the region. 


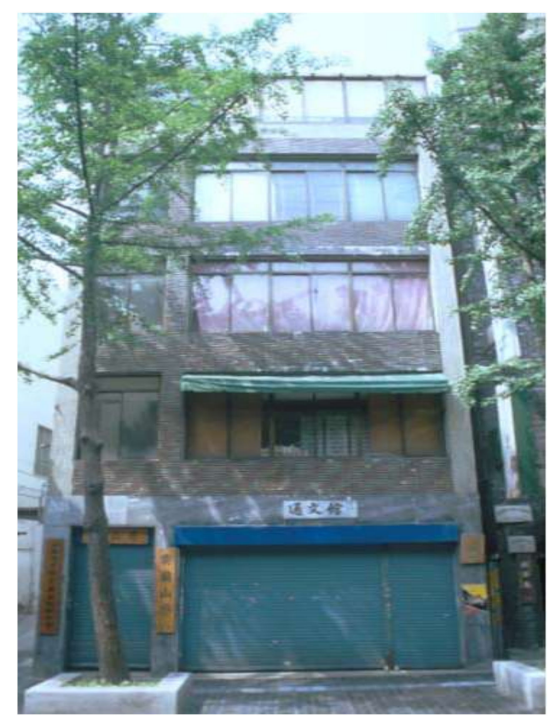

(a)

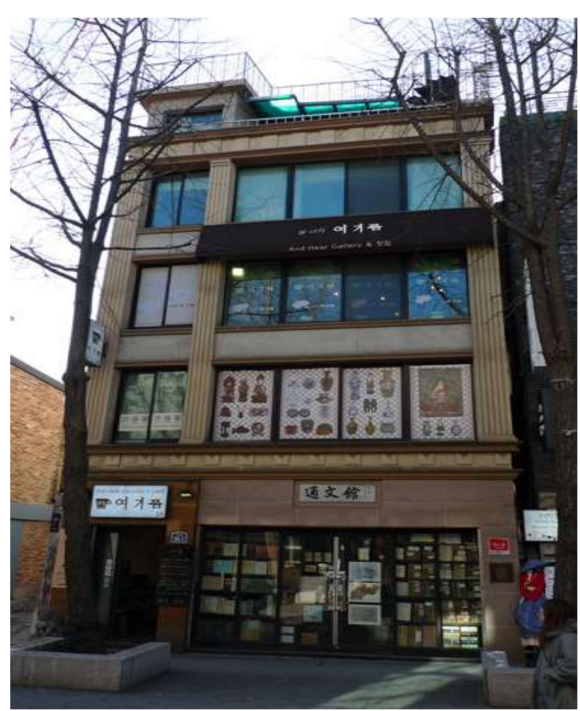

(b)

Figure 15. Façade renovation in Gwanhun-dong 147's building. (a) before; (b) after.

\subsection{Heritage Value of Roadside Commercial Buildings in Regionality and Sustainability}

Regionality is sustainable from the past to the present, as evidenced by the façade renovation of the roadside commercial buildings analyzed in this study. Although economic research suggests that it is alienated from reinvestments, such as new construction, the commercial activities and buildings that have endured in Jongno embody the historicity and regionality of the region. During that time, the residents' social activities and the region's buildings have been both preserved and changed, creating the identity and regionality of a specific region while maintaining its social and cultural value. The modern development method of urban regeneration through complete demolition sacrifices these values. For example, complete demolition and new construction of large-scale lot and large buildings left the Cheongjin-dong region devoid of its previous historicity and identity. Most of the region's merchants were forced to leave, and the atmosphere created by the old streets and buildings disappeared. Due to this undemocratic development method that failed to consider harmony among social groups, the region's cultural value was lost, and its regionality and sustainability disappeared. Thus, the tangible and intangible traditional value preserved in the existing regional commercial areas through façade renovation projects of the Jongno region should be acknowledged as regional development that secures diverse social activity, harmony among social groups, and sustainability. However, the façade renovation projects investigated were not without faults. In cases where only the façade was renovated, the internal space remained old, leading to issues concerning safety and convenience and inviting criticism that the external façade and internal space are distinct from one another. In addition, there is the problem of preserving regional placeness without improving city infrastructure, such as city street networks, parking facilities, and so on. Placeness is changeable, and it cannot endure without adapting to meet changing times. Therefore, regionality receptive to change must be maintained.

Given this, the regionality and sustainability within Jongno's temporal history must be acknowledged. Historical regionality, especially, has heritage values, as described in Section 2, and these values are acknowledged as "age value" [10]. In contrast to high-end architecture, ordinary architecture is necessarily lacking in economic resources, information, technical skill, and design quality. Most architecture relevant to old city center regions is ordinary architecture, and a large number of these are commercial buildings. Commercial buildings must have various smarts that match their surroundings, cultural influences, and contemporary trends. Therefore, commercial buildings as ordinary works of architecture are important objects that maintain historical sustainability 
and demonstrate the heritage value of a region. Sustainability through renovation is a method for maintaining roadside commercial buildings in the city center for a long time, while still adapting to change. As mentioned previously, façade renovation is the reasonable and practical method for adapting to change, allowing buildings to erect trendy façades at minimum cost. Such partial adaptations maintain the existing heritage while changing to suit the contemporary circumstances.

Examination of the 41 buildings that underwent renovation reveals the following characteristics:

(1) In commercial areas, the medical industry, jewelry industry, distribution industry, service industry, light industry, and entertainment industry have remained, in high concentration. Table 1 shows that the buildings operate with the same industries occupying the space as were there before renovation, or similar new industries matching the regional commercial area. Furthermore, in many cases, the same businesses occupy the space before and after renovation. This historical regionality also appears in the flow of commercial areas. Within the scope of the research subjects, as shown in Table 1, they continue to inherit the characteristic of segmented areas. Therefore, commercial areas are a factor in maintaining historical regionality. From a heritage perspective, commercial areas inherit their flow from the 1950s-60s period, and can be essentially traced back to the Hanyang era. From a city structure perspective, regionality has been maintained for over 600 years, and façade renovation is an expression of this trend.

(2) The trends in façade renovation show 12 cases in which the renovated façade was completely different from the original, 15 cases in which it was partly different, and 14 cases in which it was similar. Together, a total of 29 cases were similar or only partly different, confirming that renovation was largely influenced by the previous façade plan. This evidence shows that renovations sufficiently maintain historic regionality in roadside commercial buildings that require some updating in response to commercial trends.

(3) Twelve building façades renovated to be completely different from the original can be identified as having attempted to change to fit the current situation. This results in a partial change in the entire Jongno region. Therefore, the heritage value of Jongno's historical regionality can be identified as "age value," as defined by Riegl or "mutable," as defined by Marta de la Torre [10]. That is, the slow change of the region itself can be viewed as its heritage, and maintenance of the region's sustainability is thus an advantage. In another light, façades renovated to be completely different suggest a future direction for Jongno's regionality by adding new symbolism of the contemporary situation. Rather than "pure" heritage value, which emphasizes historicity, this heritage value searches for methods of sustainability while adapting to the present.

(4) The Jongno region is an old city center with a history full of various heritage factors. The recent trend of discovering the value of cultural heritage can be seen as a countermeasure against the decline of old city centers into economic slums. The cultural heritage value of a region as a whole does not needs to freeze at a certain point in time. Traces of eras in the region's history can be called cultural heritage.

\section{Conclusions}

The Jongno region was the city center of Seoul for 600 years following the Joseon period, and functioned as a center of politics, administration, economics, culture, and so on for all of Korea. It retained its role as the central commercial area even during the rapid modernization of the 1960s, but has since gradually lost its position, and is currently outdated and old. However, although the commercial areas in the city center may have declined, they have endured for decades and are still maintained, as is Jongno's role as a center of history and culture. Therefore, the smaller areas within the region each demonstrate unique regionality based on their commercial areas, and they maintain sustainability by making small changes to their commercial activities and buildings to adapt to the changing times. With the exception of a few areas that have undergone large-scale urban redevelopment, the region's buildings, which were built by the previous generation, have aged and grown outdated or been renewed through façade renovation. 
This paper targets 41 buildings in the Jongno region that were built in the 1950s-60s and underwent façade renovation, aiming to analyze the meanings of the renovation trend with respect to the region's commercial areas. The buildings investigated are used as commercial buildings in line with each region's specialized commercial activities or as ordinary neighborhood commercial facilities. Façade renovations can be divided into cases that are completely different from, partly different from, or similar to the previous façade. In cases completely different from the previous façade, panels and glass curtain walls were widely used as finishing materials, and the goal was to establish a completely new image distinct from the façade designs popular in the past. To this end, new materials and trendy designs are used to promote a new image and differentiate the building from the previous commercial activity. In cases partly different from or similar to the previous façade, stone was frequently used as a material. In many such cases, similar stores occupied the space before and after renovation, so the commercial usage did not change greatly, and similarities are visible in the façade design. Façade renovation of roadside commercial buildings as part of urban architecture maintains the regionality of the commercial while demonstrating sustainability that adapts to the changing times. The age value in the past, present, and future of these structures must be acknowledged as heritage value. Buildings, renovated buildings, and streets currently maintained in Jongno, as well as preserved or newly added commercial activities all create urban landscapes. These urban landscapes hold memory and identity from the past, and serve as the cultural heritage that includes today's everyday needs. Here in Jongno, merchant communities and the city's residents are making places in the city center and will continue to do so in the future. This small-scale preservation development, such as façade renovation, can overcome the problems of undemocratic urban redevelopment through complete demolition and loss of historicity and regionality by maintaining the regionality and sustainability connected to the commercial areas of each region.

Author Contributions: The authors contributed equally to the development of the research.

Funding: This research was supported by Basic Research Program through the National Research Foundation of Korea (NRF) funded by the Ministry of Education (2018S1A5A8030315).

Conflicts of Interest: The authors declare no conflict of interest.

\section{References}

1. Yung, E.H.K.; Langston, C.; Chan, E.H.W. Adaptive reuse of traditional Chinese shophouses in urban renewal project in Hong Kong. Cities 2014, 39, 87-98. [CrossRef]

2. Park, C.-H. A Street Regeneration Plan for Small and Medium-sized Cities, Utilizing Historic and Cultural Heritage-Focused on the Modern Buildings of Chung-Ang Street in Ganggyeong, Nonsan. J. Urban Des. Inst. Korea Urban Des. 2013, 14, 49-66.

3. Jae-Young, L.E.E. Modern Forms of Ordinary Architecture in Seoul's Jongno District in the 1950-60s and Their Significance. Korea J. 2017, 57, 90-127.

4. Heidegger, M. Being and Time; State University of New York Press: New York, NY, USA, 2010; p. 108. ISBN 9781438432762.

5. Norberg-Schulz, C. GENIUS LOCI: Paysage Ambiance Architecture; Pierre Mardaga Editeur: Bruxelles, Belgium, 1981; pp. 5-8. ISBN 2870091478.

6. Jokilehto, J. Consideration on authenticity and integrity in world heritage context. City Time 2006, 2, 1-16. Available online: http:/ / www.ct.ceci-br.org (accessed on 9 September 2018).

7. Auclair, E.; Fairclough, G. Living between past and future, An introduction to heritage and cultural sustainabilty. In Theory and Practice in Heritage and Sustainability between past and Future; Routledge: London, UK; New York, NY, USA, 2015; p. 9.

8. Lapierre, É. Identification d'une Ville: Architectures de Paris; Picard: Paris, France, 2002; p. 15. ISBN 290751377X.

9. Venturi, R.; Brown, D.S.; Izenour, S. Learning from Las Vegas; The MIT Press: Cambridge, MA, USA, 1972.

10. Riegl, A. Moderne Denkmalkultus: Sein Wesen Und Seine Entstehung; Braumüller, W., Ed.; BiblioBazaar: Charleston, SC, USA, 1903; ISBN 9781359865304.

11. De la Torre, M. Values and Heritage Conservation. Herit. Soc. 2013, 6, 155-166. [CrossRef] 
12. Jeon, W.-Y. Commercial Quarters and Merchants in Modern Jongno Street. In Jongno; Time, Place, Person-The Study of Seoul's History in 20th Century; The Institute of Seoul Studies: Seoul, Korea, 2002; pp. 131-135. ISBN 9985831380.

13. Merlin, P.; Choay, F. Dictionnaire de L'urbanisme et de L'aménagement, 2nd ed.; Presses Universitaires de France: Paris, France, 2009; p. 154. ISBN 9782130570288.

14. Nam, G.-B. The Change of Economic Landscape in Jongno-From commercial Economy to Symbolic Economy. In Jongno; Time, Place, Persons-The Study of Seoul's History in 20th Century; The Institute of Seoul Studies: Seoul, Korea, 2002; pp. 211-219. ISBN 9985831380.

2018 by the authors. Licensee MDPI, Basel, Switzerland. This article is an open access article distributed under the terms and conditions of the Creative Commons Attribution (CC BY) license (http://creativecommons.org/licenses/by/4.0/). 